\title{
Developments in water dams and water harvesting systems throughout history in different civilizations
}

\begin{abstract}
The use of water for domestic and agricultural purpose is not a new phenomenon. It has been used throughout centuries all over the world. After food, water is the basic component of human life and their settlement. This paper considers developments in water dams and water harvesting systems throughout history in different civilisations. The major component of this review consists of hydraulic dams during Pre-Historical Time, Bronze Ages (Minoan Era, Indus Valley Civilization, Early Ancient Egyptian Era, Hittites in Anatolia, and Mycenaean Civilization), Historical Period, (PreColumbian, Archaic Period, Classical Greek and Hellenistic Civilizations, Gandahara and Mauryan Empire, Roman Period, and early Chinese dynasties), Medieval times (Byzantine Period, Sui, Tang and Song Dynasties in China, Venetian Period, Aztec Civilization, and Incas) and Modern Time (Ottoman Period and Present Time). The main aim of the review is to present advances in design and construction of water dams and water harvesting systems of the past civilizations with reference to its use for domestic as well as agricultural purposes, its impact on different civilizations and its comparison to the modern technological era. In addition, emerging trends and perspectives are discussed.
\end{abstract}

Keywords: Bronze Age, Archaic, Chinese Dynasties, Classical and Hellenistic times, Indus civilizations, Medieval times, Pre-Columbians, Roman period, Ottoman period, hydraulic system, floodwater harvesting
Volume 2 Issue 2 - 2018

\author{
Alper Baba, ' ChrTsatsanifos, ${ }^{2}$ Fatma El \\ Gohary, ${ }^{3}$ Jacinta Palerm, ${ }^{4}$ Saifullah Khan, ${ }^{5} \mathrm{~S}$ \\ Ali Mahmoudian, ${ }^{6}$ Abdelkader T Ahmed, ${ }^{7}$ \\ Gökmen Tayfur, I Yannis G Dialynas, 8,9 \\ Andreas N Angelakis ${ }^{10}$ \\ 'Department of Civil Engineering, Izmir Institute of Technology, \\ Engineering Faculty, Turkey \\ ${ }^{2}$ Pangaea Consulting Engineers Ltd, Greece \\ ${ }^{3}$ Department of Water Pollution Research, National Research \\ Centre, Egypt \\ ${ }^{4}$ Colegio de Posgraduados de Chapingo, Mexico \\ ${ }^{5}$ Institute of Social Sciences and Directorate of Distance \\ Education, Bahauddin Zakariya University, Pakistan \\ 'IWA National Committee for Iran, Iran \\ ${ }^{7}$ Aswan University, Faculty of Engineering, Civil Engineering \\ Department, Egypt \\ ${ }^{8}$ School of Civil and Environmental Engineering, Georgia \\ Institute of Technology, USA \\ 'Department of Civil and Environmental Engineering, University \\ of California, USA \\ ${ }^{10}$ National Foundation for Agricultural Research (N.AG.RE.F.), \\ Institute of Iraklion, Greece
}

Correspondence: Alper Baba, Department of Civil Engineering, Izmir Institute of Technology, Engineering Faculty, Gulbahce, Urla, Izmir,Turkey, Email alperbaba@iyte.edu.tr

Received: December 20, 2017 | Published: March 23, 2018

\section{Introduction}

From the early civilizations, rainwater harvesting projects have been implemented in regions with uneven water distribution, arid and semi-arid climatic conditions. ${ }^{1}$ The main objectives are to protect people from floods and to provide them with water during drought conditions. ${ }^{2,3}$ Water harvesting structures depend on source of water to be harvested (e.g. surface water, rainwater, storm water, and groundwater). They range from:

a. Individual domestic rainwater tanks,

b. Collection and reuse of all precipitations on large industrial or agricultural sites,

c. Community wetlands for treatment and storage,

d. Aquifer recharge for storage and recovery to

e. Large-scale dams. ${ }^{2}$

The scientific achievements in the field of hydraulics of large-scale dams have a very long history. ${ }^{1}$ There are examples of large-scale dams in many countries. Some of them had been operated for centuries. Dams had been practiced in Mehrgarh and Mesopotamia since the Neolithic times, ca. 7,000-3,200 BC. Thereafter, during the Bronze Age (ca. 3,200-1100 BC), dams were built in south-eastern Greece and Indus valley by the necessities to make efficient use of natural resources, to make civilizations more resistant to natural hazards, and to improve the standards of life..$^{4-7}$ Rapid technological progress in the twentieth century created disregard for past dam construction technologies. However, there are some unresolved problems related to dams. In the developing world, such problems are intensified to an unprecedented degree. Hence, valuable insights into ancient dams relevant to their apparent characteristics of durability, adaptability to the environment, and sustainability should be helpful in facing such problems. Note that dam construction technological developments in several civilizations are the underpinning of modern achievements in hydraulic engineering. It is the best proof that: Probing the past and facing the future. The aim of this review is not an exhaustive review of what is known today about ancient dams, their related technologies and use worldwide. Rather, some characteristic examples in selected fields that chronologically extend from the prehistoric times to the modern times are presented (Figure 1). The evolution and hydraulic characteristics of dams throughout centuries with emphasis on major achievements are presented and discussed while focusing on design and construction technologies. The examples and management practices presented and discussed (not widely known among engineers) may have some importance for hydraulic engineering even in modern times. 


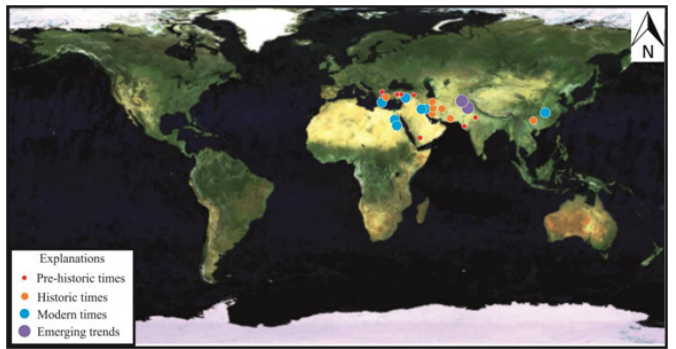

Figure I Water dams in different historical civilizations.

\section{Pre-historical time (ca. 7000 - 650 BC) \\ Eshnunna/babylonia, mesopotamian, and mehrgarh empire (ca. 4000 - 2500 BC)}

Great civilization was developed very early between Euphrates and Tigris in Mesopotamian on basis of irrigation. The Tigris, in particular, was a source of irrigation water and therefore Marduk or Nimrud Dam was allegedly built in $c a$. 2500 BC near Samarra, Baghdad. During the prehistoric time, Mehrgarh, one of the most important Neolithic (ca. 7000-2500 BC) sites in archaeology, lies on what is now the "Kachi plain" of today's Balochistan, Pakistan (Figure 2A). It is one of the earliest sites with evidence of farming (wheat and barley) and herding (cattle, sheep, and goats) in South Asia". ${ }^{6}$ The site is located near the Bolan Pass, to the west of the Indus River valley and between the present-day Pakistani cities of Quetta, Kalat, and Sibi. Most of the workers have opined that they have the ability of water logging in the seasonal torrents and to utilize it for the purpose of farming and domestic use. The Sindh Kohistan region located between main hilly ranges of Baluchistan and Indus alluvial plains is a scattered low-lying hilly area with grave soil, once covered with covered with alluvial soil suitable for cultivation purposes. It is an alluvium rich valley. The main hilly sequences of Sindh Kohistan are Lakhi, Kambhu, Badhar, Bhit, and Dumbar. ${ }^{7}$ Archaeological investigation shows that human beings living there had learned to utilize the rainwater efficiently and established excellent water storage system known as "Gabar Bund"; where rainwater was collected artificially for agriculture and other usages. Taung valley is located within this region, and more specifically it is bordered with Bandak and lower extremes of Khirthar Range from east and Dumbar and Gaz ranges in the west longitudinally (Figure 2B). During the survey of the region, stone walls built along slopes in association with torrents were noticed. The function of these walls was to trap and/or collect water for various purposes such as terracing fields, making water tanks, diverting and channelizing reservoirs (Figure 2C). There were two types of water control systems:

a. The Kach system, by which alluvial soil was accumulated behind the steps of low dam laid across the drainage slope and

b. The reservoir dam.

Quddus ${ }^{7}$ further mentioned two types of dams:

a. To restrict the natural flow of the water and release it slowly into the fields and

b. A diversionary system, where the dams were placed as weirs to divert the waters into a canal for cultivation.
The Gabarband system in Baluchistan has its beginning in the Chalcolithic Nal period based on the term "Gabar". The historians have associated this system to the "Medieval Iranian Zartushtis, who are also called Parsees". ${ }^{9}$ These Zartushtis were fire worshippers and mainly depended upon agriculture besides herding. The Gabarband system is practiced even today in the area. One of the Gabarband was located at $25,51.00 \mathrm{~N}-67,34.05 / 14 \mathrm{E}$ degree, near Khirthar range. The existing wall measures $28 \times 5 \times 2 \mathrm{~m}^{3}$ along the western side, while along the eastern side, it measures $18.30 \times 5.80 \times 4 \mathrm{~m}^{3}$. This side is provided with an extra support of two other walls. In its general scheme, the stone slab wall was erected and filled with soil and gravels. A rivulet flowing through seems to had destroyed its eastern portion (Figure 2D). Another Gabarband located at 25, 49.25N $-67,31.55 \mathrm{E}$ degree is a stone wall strategically built to collect the water or divert its flow towards the mainstream. A total of three walls is visible in sequence oriented towards the vast valley in between Gaz and Khirthar, Sind province Pakistan (Figure 2D).

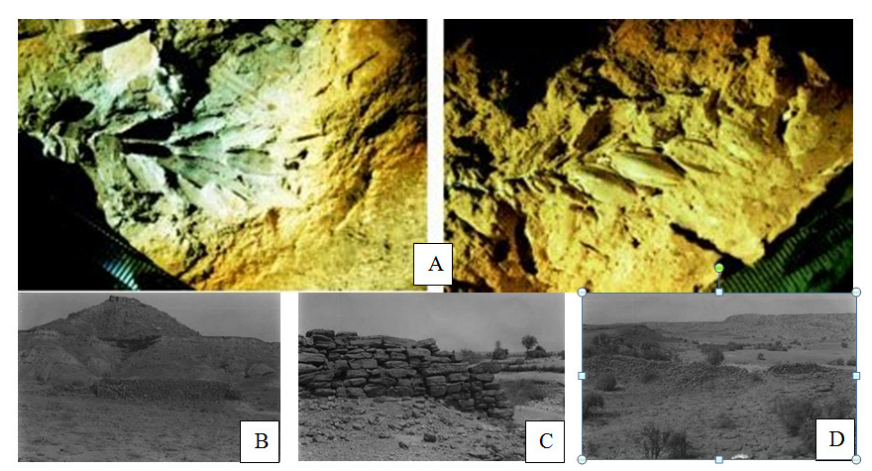

Figure 2 (A) Evidence of Wheat cultivation at the remains of Mehrgarh, Balochistan; I (B) Gabar band wall to divert flow of water at Tug Valley, (C)Sind; (D) Walls on the rivulet to close/restrict the flow of water and to divert the water towards slope, respectively, in Pakistan. ${ }^{8}$

\section{Minoan era (ca. 3200 - I 100 BC)}

Pseira dams: In Pseira (in the Island of Crete) an increase in the number of inhabitants and the change in the climate created problems around $2^{\text {nd }}$ millennium $\mathrm{BC} .{ }^{10}$ At that time a complex water management system to control and to conserve water was constructed. That system was built in ravines that extended from island's southeast coast up to the hilly landscape into the interior of the island. They consisted of groups of small check-dams to slow the progress of runoff from precipitation combined with massive stone and soil dams to create reservoirs and retain walls to prevent erosion from filling the basins with silt. ${ }^{11}$ The large Pseira dams were the main features of the system constructed in the ravines, and they would have involved more individual labor than the retaining walls.

The intensive survey of Pseira Island recorded all of the archaeological features visible on the surface, including the stone and soil dam, located in southeastern part of the island, described in the literature as Dune and Middle Greek flowing toward to the sea south of the town. An aerial photograph of Pseira showing its location of the features of the island is presented in Figure 3. The southernmost ravine, Dune Creek, begins at an elevation of $79.1 \mathrm{~m}$ as high in the Pseira Hills. It extends roughly in the west to the east direction for a distance of $c a .451 \mathrm{~m}$ until it terminates at the sea near a consolidated 
sand dune. ${ }^{11}$ The major dam (called M9 by Betancound [11]) was constructed by unconsolidated local materials, i.e. large blocks of stone and soil as bonding material (Figure 4A). The major technical parameters of the main dame at the Dune Greek are shown in Table 1. A similar dam but much smaller was constricted in Middle Greek. The water management system in Dune Creek consists also two and five check-dams upstream and downstream, respectively. Also, a small pool (dexameni) was constructed in the ravine downstream of the dam. These structures would have reduced the water flow and lessened the amount of soil erosion during the rainstorm event. The excavation in 1989 uncovered a substantial amount of information about the history of the dam and its process of construction (Figure 4B). It was built with local stones. The largest stones were over $1.5 \mathrm{~m}$ in length, and they were placed in a way that indicated careful prior planning.

Table I The major parameters of the main dam"

\begin{tabular}{ll} 
Parameters & Values \\
Elevation & $32 \mathrm{~m}$ as \\
Length & $15.5 \mathrm{~m}$ \\
Height & $3.62 \mathrm{~m}$ \\
Thickness & 2.5 to 2.8 as preserved, but \\
Capacity of & $\mathrm{m}$ at the missing center. \\
reservoir & $500-600 \mathrm{~m}^{3}$ (estimated). \\
Dated & $\begin{array}{l}\text { Ca. } 1600-1450 \text { BC. The upper } \\
\text { reconstructed in the Byza } \\
\text { th }\end{array}$ \\
\hline
\end{tabular}

Figure 3 An aerial photograph of Pseira showing the location of the features of the island."
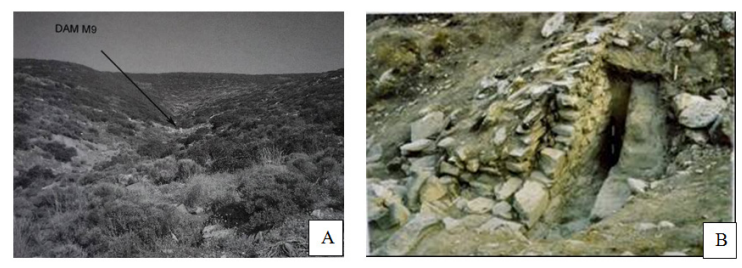

Figure 4 The main Dam (M9): (A) looking upstream in 2010. (B) as seen from the uphill side in $1990 .{ }^{\prime \prime}$

Dam at choiromandres: The case study of Choiromandres valley describes an integrated management system over an area of 7.5 ha that ensured water for irrigation, protected soil from erosion, and to a certain degree protected the areas downstream from floods. The significance of this case lies within the fact that all these constructions and systems took place during the Minoan times about 2000 BC. The case of Choiromandres could offer insight to other archaeological sites in Crete, contributing to a better understanding of the Bronze Age practices related to the management of the water resources. ${ }^{4}$ This wall is stoutly built in megalithic masonry. It has a length of $27 \mathrm{~m}$, while its height currently reaches $3.10 \mathrm{~m}$. It was erected during the Neopalatial period $(c a .1750-1430 \mathrm{BC})$. The wall is traversing the streambed, bridging the gap between the protruding rocks that form the sides of the ravine. The position of the wall and its particularly strong construction imply that it was a dam aiming to retain the swiftly flowing water. ${ }^{4}$ The wall is substantially thicker at its base to ensure the necessary stability. The east channel was formed on the surface of the rock, which might have served as a funnel for diverting excess rainwater. The dam must have been built during the dry summer months when the ravine was dry. The upper part of the wall was reconstructed during the late Classical and/or Hellenistic period. A plan and view of the main dam and check dam at Choiromandres are shown in Figure 5.
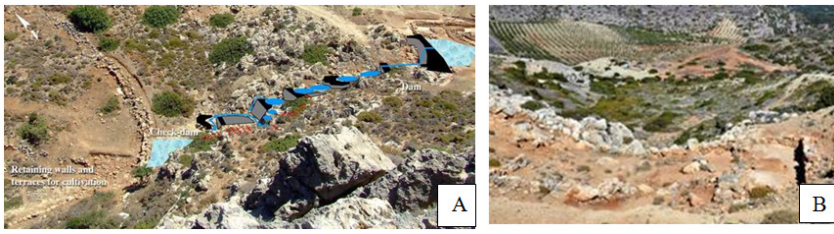

Figure 5 Minoan dams: (A) Plan of irrigation practices in the valley of Choiromandres, Zakros 4 . (B) view of the major dam (with permission A Angelakis).

Dam at gournia: Gournia was a Minoan town located in the north of the Isthmus of Ierapetra near Pahia Ammos (Figure 6). It gives a visitor the best picture of what a Late Bronze Age (ca. 1500 BC) town looked like. Gournia was a regional production center of bronze tools and weapons, domestic objects, pottery and stone vases. It was an active trade emporium with overseas connections to other parts of the Aegean and the Near East. It was the palatial administrative center for the Mirabello region. The town was bordered to the west by a river, which in Minoan times ran all year round. Across the riverbed, approximately $120 \mathrm{~m}$ from the present shoreline, the stub of a large wall protrudes out from the west bank of the river. This structure (Figure 7A) consists of two outer walls built of massive cyclopean boulders with a total width of approximately $4 \mathrm{~m}$. The interior is packed with Minoan sherds, pebbles, and stones. Pottery was found nowhere else around the dam except within its rubble core. One can make out three courses on the south face, which is preserved to a height of $1.40 \mathrm{~m}$. A second, similarly constructed wall was found $20 \mathrm{~m}$ to the south just out of the west bank of the river. Constructed two exterior faces of boulders (Figure 7B), and the wall (width. 1.90m) are preserved to a length of $9.40 \mathrm{~m}$, and its north face has two courses preserved to a height of about $1 \mathrm{~m}$. Between these walls, there was a rubble packing with worn MM III-LM I sherds. The location of these two structures at the mouth of the river within the riverbed and their construction argue for their identification as dams. If wholly preserved, the dams could have crossed the river, creating a reservoir of water for the settlement at Gournia. Based on the extent of the upland drainage area feeding the river and the large size of the waterborne boulders in its bed, the geoarchaeologist Eberhard Zangger has hypothesized that the river was perennial during the Bronze Age. If correct, this would mean that Gournia had a plentiful supply of water year-round. ${ }^{12}$ 


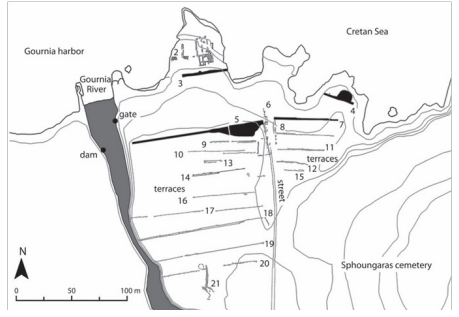

Figure 6 Site of the Gournia dams. ${ }^{12}$

\section{Indus (harappans) valley civilizations (ca. 2600- 1900 BC)}

The Indus civilization is best known through the excavation of located in Mohenjo-daro Sind province of Pakistan, about $40 \mathrm{~km}$ from Larkana town. ${ }^{13}$ A similar and larger ruin, Harappa, is located some $644 \mathrm{~km}$ northeast of Mohenjo-daro in Punjab province, Pakistan. The third site of Lothal, which was discovered almost 60 years ago, is located about $7 \mathrm{~km}$ away from Ahmedabad-Bhavnagar highway, India. ${ }^{14}$ Dholavira is an archaeological site in Bhachau Taluka of Kutch district, in the state of Gujarat in western India. The kind of efficient system of Harappans of Dholavira, developed for conservation, harvesting, and storage of water speaks eloquently about their advanced hydraulic engineering, given the state of technology. ${ }^{15}$ One of the unique features of Dholavira is the sophisticated water conservation system of channels and reservoirs, the earliest found anywhere in the World and completely built out of stone, of which three are exposed. Dholavira had massive reservoirs. They were used for storing the fresh water brought by rains or to store the water diverted from two nearby rivulets. This clearly came in the wake of the desert climate and conditions of Kutch, where several years may pass without rainfall. A seasonal stream, which runs in the north-south direction of the site, was dammed at several points to collect water (Figure 8). They are about $7 \mathrm{~m}$ deep and $79 \mathrm{~m}$ long. Reservoirs skirted the city while Citadel and bath are centrally located on raised ground. ${ }^{16}$
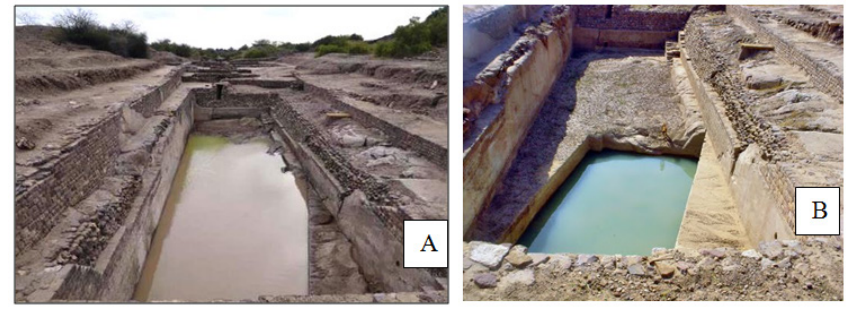

Figure 8 Hydraulic Engineering Indus Civilization at Dholavira, Rann at Gujrat: (A) Full water view. (B) Dry View. ${ }^{17}$

Dockyard at lothal: The dominant sight at Lothal is the massive dockyard, which has helped make this place so important to international archaeology. Spanning an area of $37 \mathrm{~m}$ from east to west and nearly $22 \mathrm{~m}$ from north to south, the dock is said by some to be the greatest work of maritime architecture before the birth of Christ. ${ }^{17}$ To be sure, not all archaeologists are convinced that the structure was used as a dockyard and some prefer to refer to it as a large tank that may have been a reservoir (Figure 9A). It was excavated near Sabarmati River, which has since changed course. The structure's design shows a thorough study of tides, hydraulics and the effect
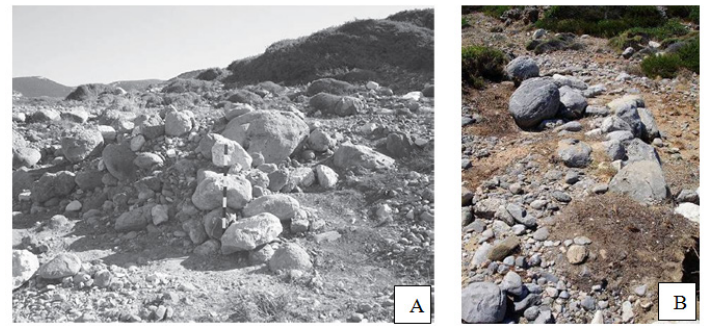

Figure 7 View of the dam: (A) Westward of outer. (B) west of inner dam. ${ }^{12}$

of sea water on bricks. Ships could have entered into the northern end of the dock through an inlet channel connected to an estuary of the Sabarmati River during high tide. The lock gates could then have been closed so the water level would rise sufficiently for them to float (Figure 9B). An inlet channel $1.7 \mathrm{~m}$ above the bottom level of the $4.26 \mathrm{~m}$ deep tank allowed excess water to escape. Other inlets prevented siltation of the tanks and erosion of the banks. After a ship would have unloaded its cargo the gates would have been opened to allow it to return to the Arabian Sea waters in the Gulf of Cambay. ${ }^{18}$ Archaeologist findings from the excavations testify the trade with ancient Egypt and Mesopotamia. The hydraulic knowledge of the ancient Harappans can be judged by the fact that boats had docked at Lothal in the 1850's.

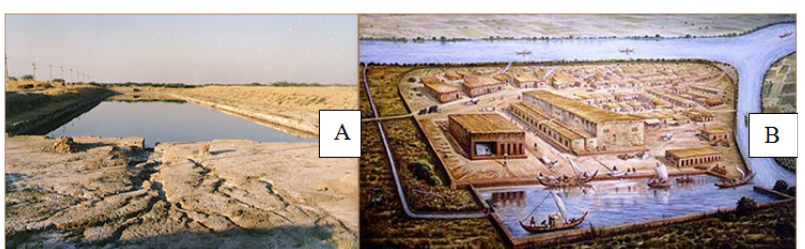

Figure 9 Dockyards at Lothal and Courts: (A) Archeological View. (B) Gates and flow directions Model. ${ }^{19}$

\section{Early ancient egyptians (ca. 4000 BC-I 850 BC)}

The first successful efforts to control the flow of water were made in Mesopotamia and Egypt, where the remains of the prehistoric irrigation works still exist. In Egypt, the building of dams at right angles to the flow of the Nile, separating the Nile Valley into basins, precedes the old Kingdom. Dikes, built along the banks of the river and the basins covered between 400 and 1700 hectares, were carefully leveled. The river water was diverted into canals on either side of the Nile. During the highest flooding (towards the end of September) most of the Nile Valley was covered with water, only villages and cities, built on higher ground, were above water. When the water level reached the mouths of the canals, the dams separating the canals from the river were opened and the basins and canals flooded. When the highest water level was reached, one to two meters above the ground, the water was left standing until it evaporated or was drained off during the next two months. To keep the system working, the canals had to be dredged yearly to prevent their clogging; the levees had to be raised, and smaller ditches had to be re-excavated..$^{20}$ The embankment dams had been used very early in the ancient historical periods of Egypt. There are many records referring to these dams. Van Loon ${ }^{21}$ reported that dam construction began about 6000 years BC in Egypt, which was used mainly for flood control and irrigation purposes. However, potable water supply and irrigation systems in Egypt have 
existed from the fourth millennium BC. Many small earthen dams and irrigations canals were built by ancient Egyptian to manage the Nile River water. The remains of one of the oldest and greatest known dams, Sadd-el-Kafara, built during the period of 2950 to 2750 BC were found in Egypt in the Wadi el Garawi, $30 \mathrm{~km}$ south the capital city, Cairo. ${ }^{22}$ The dam site has coordinates of $29^{\circ} 47^{\prime} 43.00^{\prime \prime} \mathrm{N}$ and $31^{\circ} 25^{\prime} 55.00^{\prime \prime}$ E. The dam site and a sketch for its dimension are shown in Figure 10. It was 107 to $113 \mathrm{~m}$ in crest length and 11 to $14 \mathrm{~m}$ in height. It was consisted from two masonry shoulders supporting a central core of sand and gravel. The core consisted of 60,000 ton of earth and rock-fill. ${ }^{23}$ The downstream wall was about $37 \mathrm{~m}$ wide, the upstream wall was about $29 \mathrm{~m}$ wide and they contained around $2,900 \mathrm{~m}^{3}$ a mass of materials. These upstream and downstream walls were constructed from limestone ashlars. Each stone was roughly $30 \mathrm{~cm}$ high, $45 \mathrm{~cm}$ wide, $80 \mathrm{~cm}$ long and $23 \mathrm{~kg} .{ }^{24}$ Due to the erosion of the downstream face of the dam and lack of a spillway, it is believed that a flood destroyed it. The crest of the dam sloped towards the center might have been used as a spillway. However, as the top of the dam was not beheaded, it was not protected from flood water that would over-top it. During the $12^{\text {th }}$ dynasty in the $19^{\text {th }}$ century BC, the Pharaohs Senosert III, Amenemhat III, and Amenmehat IV dug a canal $16 \mathrm{~km}$ long linking the east-west. It was built to retain water during the annual flood and then release it to surrounding lands. The lake called "Mer-wer" or Lake Moeris covered 1,700 $\mathrm{km}^{2}$ and it is known today as Berkat Qaroun. ${ }^{26}$ Dams were built, sometimes for military or commercial aims in mind, at others probably for flood protection or irrigation. Herodotus claims that Menes built a dike diverting the Nile in order to protect Memphis from inundations. The Sadd elKafara in Wadi Garawi, the oldest known dam in the world, collapsed not long after its erection in the early Old Kingdom. Its purpose is unclear. ${ }^{27}$ Another dam was constructed at Semna probably during the reign of Amenemhet III (1841-1796 BC) and it was in use until the times of Amenemhet $\mathrm{V}$. It was apparently constructed in order to facilitate navigation. The dam of Senusret II in the Fayum was built to control the level of Lake Moeris. ${ }^{28}$

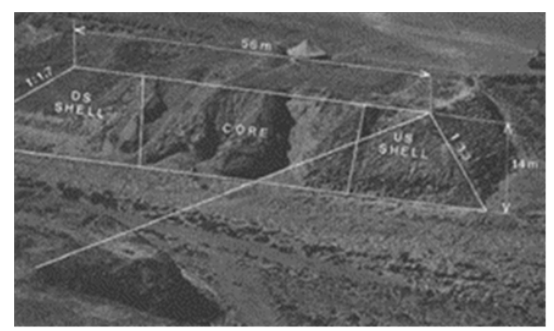

Figure 10 Sadd-Elkafara dam ruins and sketch for its cross-sectional dimensions. ${ }^{25}$

\section{Hittites in anatolia (ca. I 700-I500 BC)}

The Hittites established an empire centered on Hattusa in northcentral Anatolia around 1600 BC. Various dams were dating back to the Hittite period in Anatolia. For example, Karakuyu Dam (Kayseri) was constructed by Hittites towards the end of the second millennium BC in Anatolia. The U-shaped crest of the Karakuyu dam has a total length of $400 \mathrm{~m}$, the central part being $200 \mathrm{~m}$ long. ${ }^{29}$ There are also some other dams from that period like Eflatunpınar (Beyşehir), Köylütolu (Konya), Gölpınar (Konya), Güneykale. ${ }^{30,31}$ Alaca Höyük is one of the most significant Hittites cities established in Anatolia.
Gölpınar dam is one of the important dams in Hittite in Anatolia. The stones of the rockfill embankment have the size of a fist (Figure 11). The stones of the lower part are bigger and they seem to have been reinforced with hardpan that prevented permeability to some extent. There is no plaster between the stones but they seem to have been strengthened with clay. The length of the stone set from east to west is $15 \mathrm{~m}$. The water flowing through the canal lock enters two different canals with a difference in height of $1 \mathrm{~m}$ over the set. Water runs through those canals and flows into the main canal over the set. There is a basin for maturation or storage in the middle of the stone set which has a length of about $130 \mathrm{~m}$. The width of the basin in the middle of the stone set is $8 \mathrm{~m}$. The base of the pool is covered with clay. ${ }^{32}$

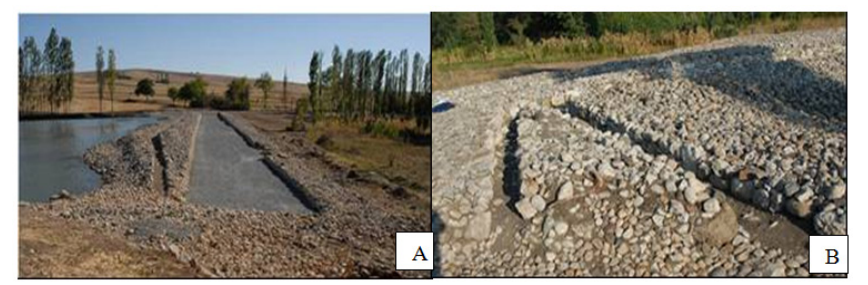

Figure I I General views from Hittite Dam in Alaca Höyük: (A)

Embankments. (B) Weirs. ${ }^{33}$

\section{Mycenaean civilization (ca. I 900- I I00 BC)}

The name of the Mycenaean civilization derives from the site of Mycenae in the Peloponnese, where once stood a great Mycenaean fortified palace. Mycenae is celebrated by Homer as the seat of King Agamemnon, who led the Greeks in the Trojan War. The Mycenaean civilization extended its influence throughout the Peloponnese, Attica, Boeotia, and Thessaly in Greek mainland but also across the Aegean, in particular, on Crete and the Cycladic islands. Major Mycenaean centers included Mycenae, Tiryns, Pylos, Thebes, Midea, Gla, Orchomenos, Argos, Sparta, Nichoria and probably Athens and represent the apogee of the Mycenaean civilization, which laid the foundations for the evolution of the ancient Greek civilization.

Dam on chavo river in mycenae: The dam is located $3.4 \mathrm{~km}$ from the Mycenae Acropolis. It is on the river Chavo and it was built in order to save the large water quantities of the river as well as those of the Perseia spring and it was also used as a bridge to cross the river. The dam had a width of almost $5 \mathrm{~m}$, a height of $4.5 \mathrm{~m}$ and length $37 \mathrm{~m}$. It was constructed with the typical technique of that period, consisted of two outer megalithic masonry walls with internal filling with stones and mortar. When the water reached the top of the dam, the lake behind it had a length of more than $100 \mathrm{~m}$ and width of about $30 \mathrm{~m}$ near the wall.

Dam of ancient tiryntha: The ancient dam of Tiryntha was constructed around $1200 \mathrm{BC}$ by the inhabitants of the ancient town of Tiryntha, which experienced very damaging floods due to a stream that drove the Argolic Gulf, passing through the city. At the same time, the transfer of large quantities of sediment deposits and the deposition at the coast caused problems in a port- which was vital for the wider space of Mycenaean Argolic field. After devastating floods in the late Bronze Age, the inhabitants decided to divert the stream to the south and away from Tiryntha. In this context, they constructed huge barrier in Tiryntha $\left(10 \mathrm{~m}\right.$ height, $300 \mathrm{~m}$ length and $35,000 \mathrm{~m}^{3}$ volume) which was made of earth and operated in conjunction with an artificial $1.5 \mathrm{~km}$ long diversion channel. ${ }^{34}$ The dam is maintained 
in good condition (Figure12). The core is made of red clayey soil, while both sides (Eastern and Western) are protected by cyclopean walls and constructed with partially refined large limestone boulders. The upper part of the eastern wall and especially the internal side has almost entirely collapsed due to erosion and removal of the stones. The northern part of the outer protective wall is strongly eroded by the floods to a width of $1.5-3 \mathrm{~m}$. The western wall is smaller and much lower than the eastern and it is not visible today.

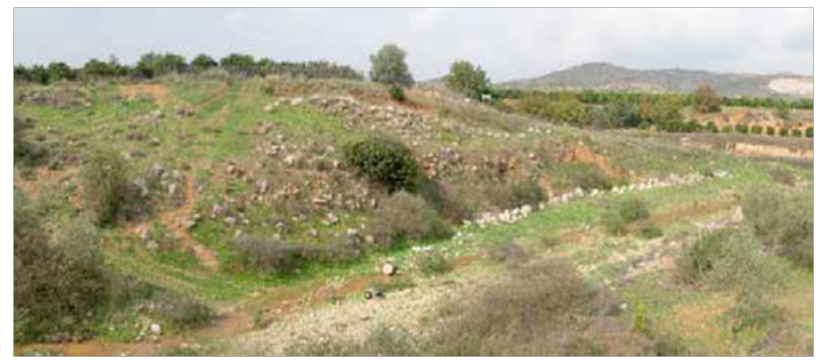

Figure 12 The main part of the Tiryntha Dam.

Dam of ancient mantineia: The Mycenaean Mantineia Dam was built on a mountain at the deepest point of the closed basin with the same name. The city and the extensive croplands were protected from the flood waters coming mainly from the south of the basin, by a dam, with retention basin approximately $15,000,000 \mathrm{~m}^{3}$. The dam was built close to the current village Skopi, 6km north-northeast of Tripoli, at a narrow location of the valley, with a length of approximately $300 \mathrm{~m}$, and height of approximately $3 \mathrm{~m}$, with impervious clay, and an artificial lake of 5 to $6 \mathrm{~km}^{2}$ surface area (Figure 13).

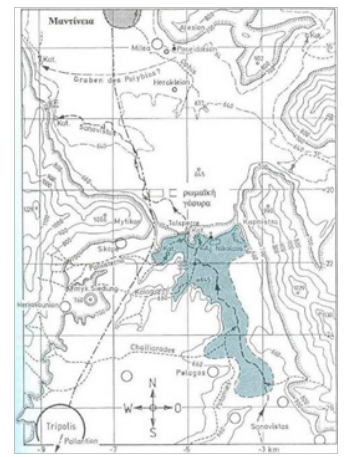

Figure 13 The dam and the artificial lake at the Mantineia Valley. ${ }^{35}$

The dam of arcadian orchomenos: The main dam was constructed in the middle of a double basin north of today's Orchomenos village and about $5.5 \mathrm{~km}$ northeast of the Levidi town. It was built during the $13^{\text {th }}$ century $\mathrm{BC}$ for the protection of the croplands, with a height of about $2 \mathrm{~m}$, width 9 to $10 \mathrm{~m}$, length over $2 \mathrm{~km}$ and lake capacity of over than $15,000,000 \mathrm{~m}^{3}$. The dam can be seen today with a height of more than $1 \mathrm{~m}$ (Figure 14).

Taka dam: Taka Dam consists a part of a land reclamation project about $6 \mathrm{~km}$ south of the city of Tripolis (Figure 15). It had a width of $8 \mathrm{~m}$, consisting of two cyclopean walls with soil and rock fragments in-between, a length of about $900 \mathrm{~m}$ and a height of over $2 \mathrm{~m}$. The lake capacity was about $10,000,000 \mathrm{~m}^{3}$.

Boedria dam: The Boedria dam was constructed on the northwest side of the Kopais basin, near the Boeotian Orchomenos on the Melas
River. It had a height of $2 \mathrm{~m}$ and length of $1,250 \mathrm{~m}^{25}$ and a lake capacity of $12,000,000 \mathrm{~m}^{3}$. It was built in order to provide irrigation water to the croplands and it has consisted of two parallel stone walls with soil and rock fragments in-between.

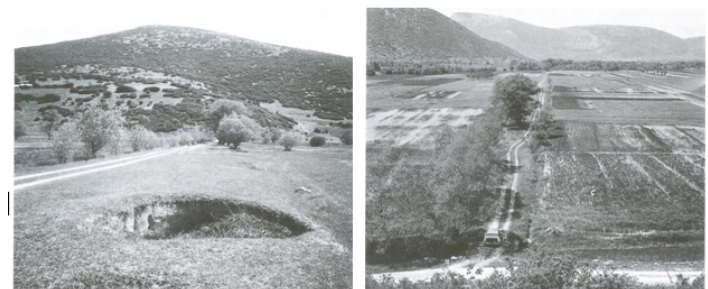

Figure I 4 The Orchomenos Dam today. ${ }^{35}$

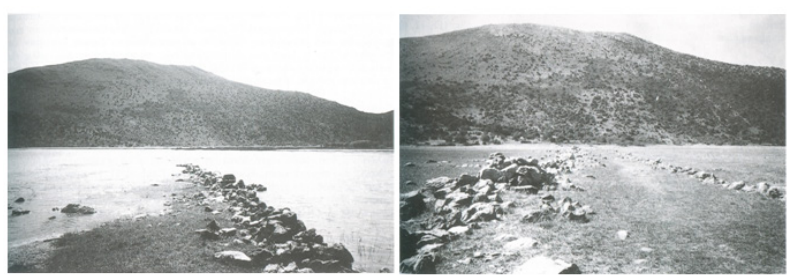

Figure I 5 The Taka Dam as it can be seen today during winter and summer time. $^{35}$

Kopais dams: Kopais, the biggest closed basin in Greece, suffered flooding problems during winter time since the early antiquity. The Minyes - Mycenaeans devised and implemented an extremely inspiring system to combat the problem. Initially, they diverted the Boeotian Kifissos river, being the main cause of the floods, to the Melas River and then, with the help of a canal and a dike along the north shore of the basin, guided the flood water to sinkholes at the northeast. So, the part of the basin north of the dike was flooded while the southern part was largely available for cultivation. The canal is a great testimony of the Mycenaean-hydraulic technology of the time, being the unique engineering project of that era in Europe. Its length was about $25 \mathrm{~km}$, width $40 \mathrm{~m}$ and depth of 2 to $3 \mathrm{~m}$. It was formed by earthen embankments up to $30 \mathrm{~m}$ wide and $2-3 \mathrm{~m}$ high, with cyclopean retaining walls on either or on the one's side (about in the first $6 \mathrm{~km}$ approx.) to prevent its erosion (Figure 16).
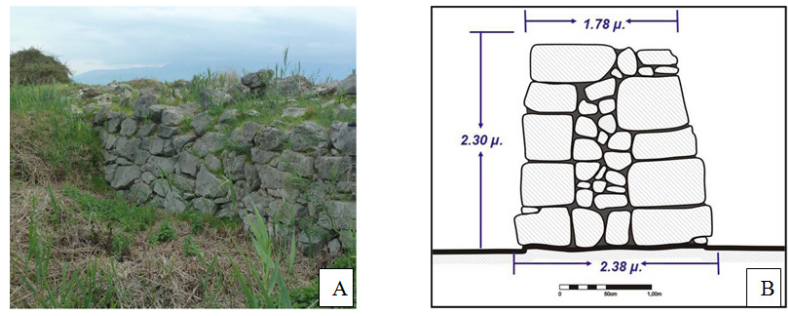

Figure I 6 View of the dam: (A) The retaining wall of the dike36. (B) Section of the dike. ${ }^{36}$

Thisve dams: The hydraulic works in the valley of Boeotian Thisve include two dams. The great dam (Thisve I), which is approximately $1.2 \mathrm{~km}$ long and $2.5 \mathrm{~m}$ high (Figure 17), and the small dam (Thisve II), which is approximately $220 \mathrm{~m}$ long and $4-5 \mathrm{~m}$. high The lake capacity of both dams was about $6,000,000 \mathrm{~m}^{3}$.

Stymfalos dam: The prehistoric land reclamation structures in the Stymfalos basin were constructed in order to prevent the flooding of 
the center of the basin. The water coming from the east was contained in a dam with the zigzag plan view, the length of $1,900 \mathrm{~m}$, the height $2.5 \mathrm{~m}$, and lake capacity $10,000,000 \mathrm{~m}^{3}$. At the west side, another zigzag dam was constructed with a stone wall and a discharge channel in front of it.

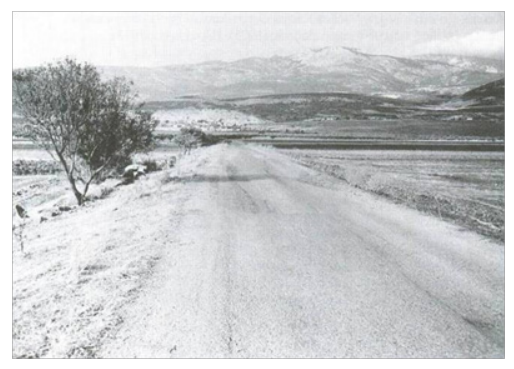

Figure 17 Today's view of the Thisve I dam. ${ }^{35}$

Feneos dam: According to the legend, the land reclamation works in the basin of Feneos were constructed by Hercules. Knauss ${ }^{35}$ states that the Olvios River was diverted with the aid of an embankment $2.5 \mathrm{~km}$ long and 2-3m high, protecting the eastern side of the basin. The Lake was drained in a sinkhole at the foothill to the south.

Petra mountain and voiviida lake walls: In the eastern part of the Thessaly plain, there was the Lake Voiveis, which, in modern times, initially was drained and currently replenished. On the southwest shore rises a group of hills with three peaks, known by the name Mountain Petra (Stone), with remnants of one of the major Mycenaean acropolises in Greece. The schematic representation of strong cyclopean walls, of several km lengths, which protected the city from the rising lake water is shown in Figure 18.

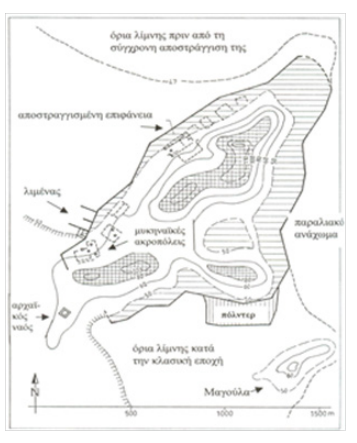

Figure 18 The protective wall of the Mycenaean city at the Petra hill in the Voiviida Lake. ${ }^{35}$

Arni-kierion dam: Remnants of large cyclopean walls, dating from the Mycenaean era, were found in front of the Arnis-Kierion hills in the center of Thessaly plain. The archaeological excavation works highlighted the section of foundations of a wall, almost 40m in length. The wall has a width of $3.5 \mathrm{~m}$ and consists of two outer flanks from large, angular stones and infill of rounded gravel and soil.

Corinth isthmus dam: The most important and impressive remains of the prehistoric period of the Temple of Poseidon of Corinth Isthmus are the large parts of cyclopean walls, which protected a specific area from floods and mainly from the undesirable deposition of sediment from the surrounding hills: soil, stones, pine needles and tree branches. ${ }^{35}$ The walls are made of local limestone with two outer flanks, filled with stones at a clayey matrix. The preserved stone base layers have the width from $3.5 \mathrm{~m}$ to $4.5 \mathrm{~m}$. The today's height is approximately $2.5 \mathrm{~m}$, while the original top layer is missing. The original height is estimated to be 3 or $3.5 \mathrm{~m}$ or more.

\section{Marib dam in old yemen civilization (ca.700 BC - 600 AD)}

Ancient Marib was the capital of the wealthy kingdom of Saba, which thrived during the first millennium BC in Yemen. Marib Dam is considered as one of the greatest achievements of engineering of the pre-industrial era. To keep the dam safe and stand for a long time; canals, gates, sluices, and spillways, and the whole system had to be waterproof. The Sabaens, ancient Yemen people, managed all this before the existence of concrete, and their dam stood for over 1,000 years, in comparison to modern dams built with advanced technology last for around 50 or 100 years..$^{37}$ The great dam of Marib was about $610 \mathrm{~m}$ long, around twice as long as the Hoover Dam in the USA. The great dam of Marib sustained the largest city in ancient southern Arabia for more than a thousand years. Today, only the sluices remain as shown in Figure 19. While it stood, it converted ancient Yemen land into a fertile oasis. It is believed that the dam was severely damaged by a Saudi airstrike in the night of May 31,2015, bringing down much of the agriculture system and converting the area into the sandy desert as it is today. ${ }^{38}$

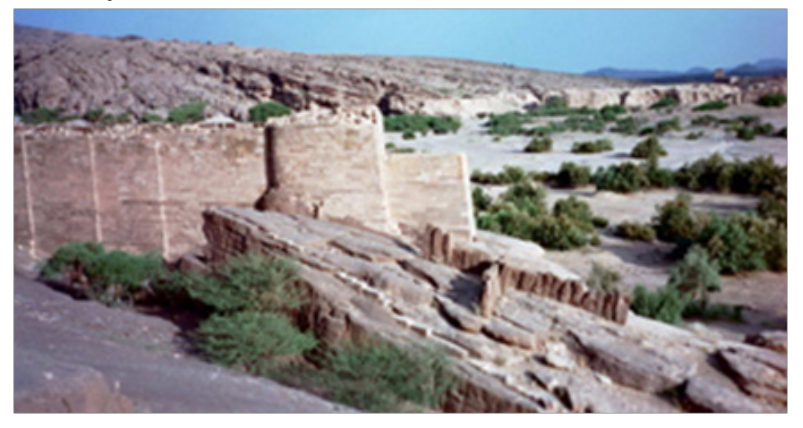

Figure 19 View Marib dam ruins in Yemen. ${ }^{37}$

\section{Other civilizations}

From the Urartu period (the first half of the $1^{\text {st }}$ millennium BC) in Eastern Anatolia, there exist various remains of dams. ${ }^{39-41}$ Some of them are still in use like the dams at Keşiş, Doni, and Süphan lakes. In Urartu period two dams were used to increase the volume of the Rusa (Kesis) lake for water supply to the later capital Rusahinili (Toprakkale) and her environment. Two of the three dams are still in use at Doni Lake and the downstream dam on Energizer creek for additional irrigation water to Tuspa (Vankale) and its surroundings. ${ }^{40}$ In the eastern part of Anatolia in Van basin and its surrounding areas, irrigation canals and dams are observable to date from the time of the Urartian Kingdom (840-590 BC) which is located in the highlands of eastern Anatolia, the Ararat plain of Armenia, and in northwest Iran. The irrigation system set up by the Urartu kingdom making use of surface water can be divided into two categories: The first one is the irrigation carried out from the Menua, or Shamram Canal which was built by King Menua in about 800 BC. This canal is only irrigation canal in the world that has been in constant use for 2795 years. The second is the irrigation carried out from Lake Keşiş (Lake Rusa) and 
the smaller dam lakes in the vicinity. The water of Lake Keşiş, which lies at an altitude of $2890 \mathrm{~m}$ to the east of Van was dammed by Rusa II (680-654 BC) and thus a large quantity of water was stored in order to meet the water requirements of the new capital, Rusahinili, and its immediate environs. By building dams on the stream flowing from the lake, a sufficient reserve to last through the summer months was accumulated. About 20 millionm $^{3}$ of water could be stored in the still-existing small dams (Figure 20). Lake Keşiş is the proof that the Urartu possessed a sound knowledge of engineering. The Assyrians developed extensive public works. Sargon II, invading Armenia in $714 \mathrm{BC}$ discovered the qanat (Arabic name) or kariz (Persian name), which is a tunnel used to bring water from an underground source in the hills down to the foothills. Sargon destroyed the area in Armenia but brought the concept back to Assyria. This method of irrigation spread over the Near East into North Africa over the centuries and it is still used. Sargon's son Sennacherib also developed water works by damming the Tebitu River and using a canal to bring water to Nineveh, where the water could be used for irrigation without hoisting devices. During high water in the spring, overflows were handled by a municipal canebrake that was built to develop marshes used as game preserves for deer and wild boar, and birch-breeding areas. When this system was outgrown, a new canal, nearly $19 \mathrm{~km}$ long, was built, with an aqueduct that had a layer of concrete or mortar under the upper layer of stone to prevent leakage. The earliest known dam is the Jawa Dam in Jordan, 100km northeast of the capital Amman. This gravity dam featured an originally $9 \mathrm{~m}$ high and $1 \mathrm{~m}$ wide stone wall, supported by a $50 \mathrm{~m}$ wide earth rampart. The structure is dated back to $3000 \mathrm{BC}$. By the mid-late $3^{\text {rd }}$ century $\mathrm{BC}$, an intricate watermanagement system within Dholavira in modern-day India was built. The system included 16 reservoirs, dams and various channels for collecting and storing water.

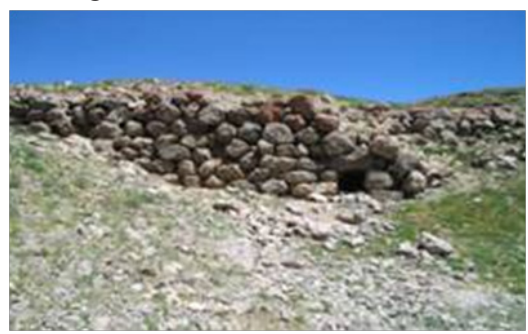

Figure 20 Ruins from Rusa Dam. ${ }^{41}$

\section{Historical times}

\section{Pre-columbian (Incas) times (ca. 2500 BC to I540 AD)}

The Incas established their empire in the southern region of today's Peru, Equador, Columbia, Mexico and the Amazonian watershed 1200 BC. During Incas periods, water supply facilities were given special consideration, and some areas were enhanced with elaborate irrigation systems. Machu Picchu is situated south of the equator by about $1,400 \mathrm{~km}$ on the eastern slope of the Peruvian Andes. The spring collection works, the main canal, and the 16 fountain of Machu Picchu represent the work of a civilization with advanced waterhandling capabilities. ${ }^{42}$ The people of Incas were descended from Inti, the Sun God. Inti commanded his son, Manco Capac, to rise out of the waters of Lake Titicaca. Manco Capac then founded the Inca tribe.
The Machu Picchu water system demonstrated that the Inca Builders were skilled in empirical hydraulic engineering methods. They were also the experts of the physical constraint of the gravity driven water system. A hydraulic analysis defined several characteristics of the Machu Picchu spring, canal, and fountain system. The hydraulic design of the 16 fountains provides adequate water jetting to enable easy filling of the ancient Inca water arybalic (Figure 21).

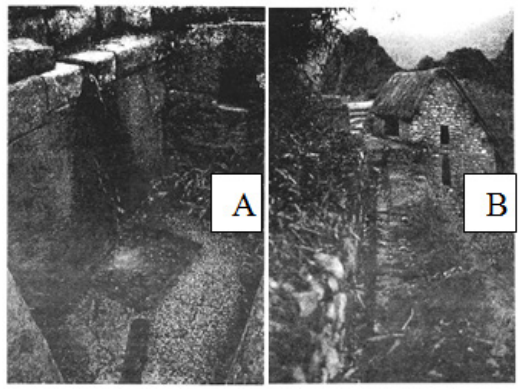

Figure 2 I Machu Picchu: (A) Fountain with inlet showing in upper left, stone basin below, orifice outlet and carved stone outlet channel, water flow. (B) Inca domestic water canal to agriculture sector. ${ }^{42}$

\section{Dams at iran}

The history of the ancient dams in Iran dates back to 3000 years and shows that ancient Iranians were among the pioneers in dam construction in their efforts to develop water resources. The Darius Dam on Kor River dates back to 2500 years. Bahman Dam in Shiraz (Figure 22A) was built more than two millennium years. 1700 years old Mizan Dam in Shushtar is still in place. Amir Dam constructed by Buyids Dynasty, $35 \mathrm{~km}$ north of Shiraz is 1000 years old (Figure 22B). Kebar Dam in the city of Ghom which has been added to the list of national heritage structure of Iran has a height of $25 \mathrm{~m}$ and it is believed to be the first arch dam built in the world about 700 to 900 years ago (Figure 23A). Kurit gravity arch dam, located close to Tabas city was built in $1350 \mathrm{AD}$. Its height is $60 \mathrm{~m}$ and it was regarded as the highest dam in the world up to the beginning of the twentieth century (Figure 23B). During the Safavid Empire (1501-1736) water engineering progressed significantly and many storage and diversion dams and bridges were constructed in Esfahan and Mashhad, some of which still exist. Khaju Bridge and diversion dam and Thirty - three Arch Bridge are two of the very famous and beautiful diversion dams and bridges in the city of Esfahan (Figure 24A) (Figure 24 B). ${ }^{43}$
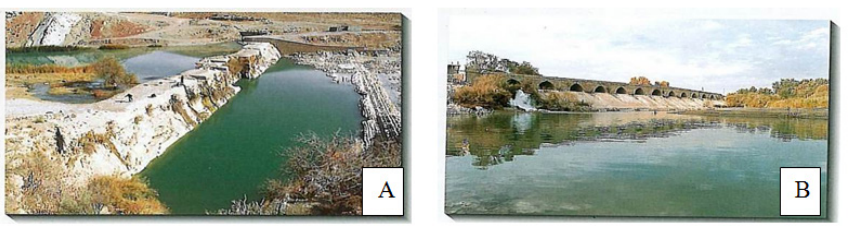

Figure 22 (A) Bahman weir dam. (B) Amir multi-purpose dam in Fars province.

\section{The archaic period (ca. 630-490 BC)}

The Archaic Stage or Period was established in New Jersey during $c a$. 8000-1000 BC an early level of culture based on hunting, fishing, and gathering of wild vegetable foods, and lacking pottery, 
the smoking pipe, and agriculture. Among archaeologists, the term "Archaic" is now generally taken to mean a period of time and/or a stage of cultural development characterized by hunting and gathering economy based upon the seasonal exploitation of natural resources by relatively small, mobile bands. It has been observed that the archaic people, particularly the Indian facts, have the masters of water storage and to use it for domestic and agriculture purposes. ${ }^{44}$
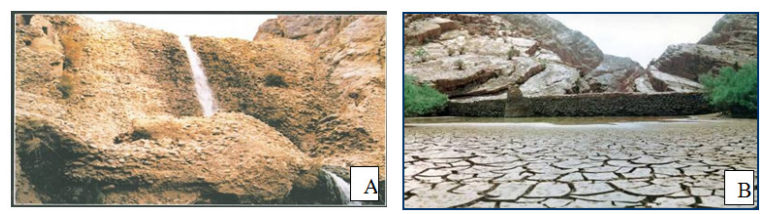

Figure 23 (A) Kebar Dam in the city of Ghom. (B) Kurit gravity arch dam in Tabas city.
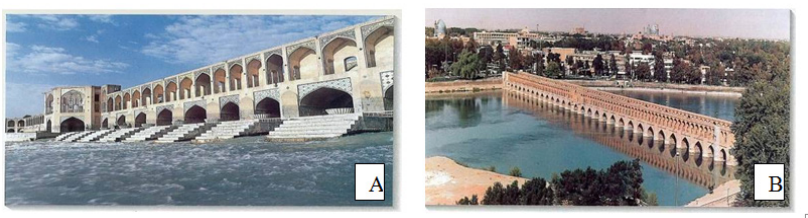

Figure 24 (A Khaju Bridge and diversion dam in Esfahan province. (B) Thirty, three Arch bridge in Isfahan province.

\section{Classical greek and hellenistic civilizations (ca. 490 - $67 \mathrm{BC}$ )}

The protection of urban areas from the destructive action of streams (floods, erosion, and sedimentation) is another case of application of hydraulic and water management technologies. Such techniques are also necessary for the development of agricultural areas, given that the most fertile areas are the flood plains of rivers. As mentioned above, large-scale projects (massive or Cyclopean type) of the latter type date back to the Mycenaean period. ${ }^{45} \mathrm{~A}$ characteristic paradigm from Classical period related to urban or suburban development is the flood protection works of Olympia and the dam of ancient Alyzia.

Alyzia dam: The ancient Alyzia dam was constructed during the Classical period of the inhabitants of the Ancient city located to the west of Aitoloakarnania in western Greece. Until recently researchers who visited the ruins of the dam, including the Murray and Knauss, expressed the view that the dam was used to retain water. However, Zarkadoulas ${ }^{45}$ presented a scenario under which the dam was built to hold sediments that might otherwise overwhelm the downstream valley and make cultivation impossible. The fact that the barrier was filled with debris very quickly after the construction supports this scenario. ${ }^{34}$ The ancient city of Alyzia is located in Western Greece on the coastline of Akarnania. Close to the city, on the fringes of the Akarnanika Mountains, lies a unique example of a hydraulic work of Greek antiquity: a stone dam, equipped with a stone carved lateral spillway (Figure 25). The exact date of its construction is unknown, but because of the city's prosperity during the fifth century $\mathrm{BC}$, this period is the most probable for the construction of the dam. ${ }^{46}$

Alfeios embankment: The characteristic geomorphological feature near the ancient Olympia sanctuary is the confluence of the Alfeios and Kladeos rivers. Flooding of the rivers resulted in limiting the usable area around the sanctuary and silting the rest. In order to overcome this situation, the engineers constructed $800 \mathrm{~m}$ long and $2.7 \mathrm{~m}$ high wall / dyke along the violent Kladeos river with Cyclopean conglomerate with four stone courses (Figure 26), together with a diversion canal, and a $1,000 \mathrm{~m}$ long, more than $2 \mathrm{~m}$ high and up to $30 \mathrm{~m}$ wide dyke along the Alfeios river. Its construction date is unknown but most probably was in the classical period, when the place took its final form.

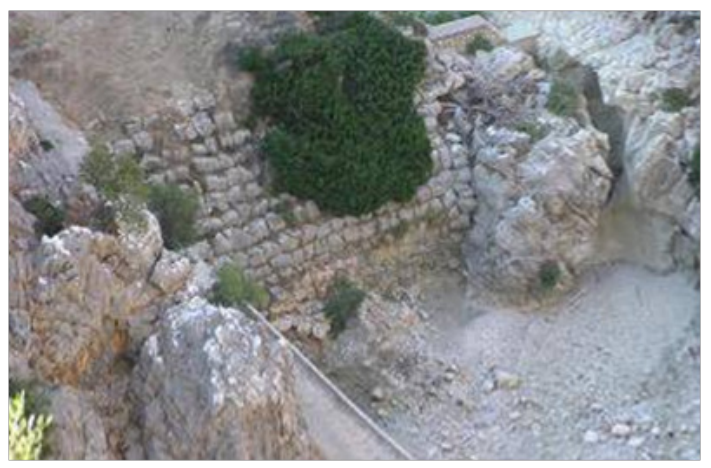

Figure 25 The dam of ancient Alyzia; general view and its spillway with its irregular shape formed by erosion through centuries (photo Angelakis AN).

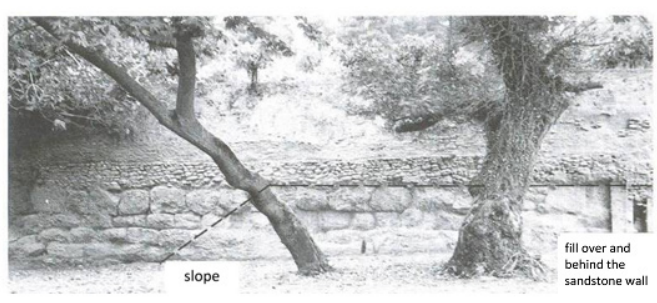

Figure 26 The beginning of the wall/dike along the Kladeos River at the north edge of the sanctuary. ${ }^{35}$

\section{Gandhara and mauryan empire (ca. Ist millennium to $322-185 \mathrm{BC}$ )}

The Arthashastra of Kautilya gives an extensive account of dams and bunds that were built for irrigation during the period of the Gandhara (Swat, Pakistan) and Mauryan Empire (India). The water supply systems were well managed within the framework of strict rules and regulations. Different types of taxes were collected from the cultivators depending upon the nature of irrigation. ${ }^{47}$

Sailaba or rod kohi system: The sailaba or rod-kohi system is widely practiced in the Sind and Balochistan provinces in Pakistan, Afghanistan, Iran, and parts of Middle East. The sailaba cultivation is done by diversion and spreading of intermittent flows of hill torrents. ${ }^{47}$ As the water comes down the hill, it is checked by a series of earthen diversion bunds (embankments). To meet their local irrigation needs small communities had constructed diversion bounds on a number of smaller streams for irrigation. The water thus checked is allowed to seep slowly down into the soil.

Khushkhaba system: The Khushkhaba system comprises in-situ conservation of incidental rainwater and catching runoff from a large uncultivated block and diverting it to cultivated fields. Fields 
receive water directly from precipitation or from localized runoff. The Khushkhaba is merely a chance cropping with a successful crop being raised on average once in five years. The main difference between the Khushkaba lands and the sailaba (flood) lands is that the catchments area of the former is small and is often not bigger than the field enclosed by the embankment or bund. Embankments are made facing the hills so that the natural gradient within the bounded area helps collect the runoff above the embankments. ${ }^{8}$ The area inside the bund is deliberately left uneven with the areas flows to the bund being the lowest (Figure 27). This is done so that, in the case of high rainfall, the runoff from adjacent areas upslope collects near the embankments and provides enough water at least to grow crops in the lower half of the fields (0.5-1\% slope), and to encourage rainfall to run off into the tilled bonded field below to increase both its soil moisture content and, consequently, the yield of the dry land crop. It is mainly practiced in Quetta-Sarwan and Zhob-Loralai areas of the Balochistan province. The area under Khushkhaba cultivation in Balochistan was estimated as 0.32 million ha in 190 and 0.34 million ha in $2000 .{ }^{47}$

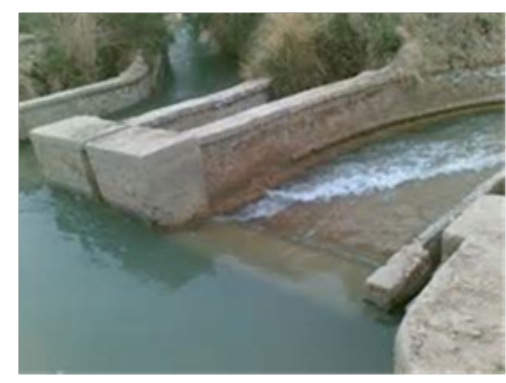

Figure 27 The Dam at Khushkhaba Balochistan, Pakistan.

\section{The roman period (ca. 67 BC-330 AD)}

The majority of dams in the Roman Near East were gravity dams and functioned on the basis that they are too massive to be affected by the pressure of the water stored behind them. ${ }^{48}$ A possible arch dam may also have existed at Dara. ${ }^{49}$ Dams of these types were in use in the Near East from the Bronze Age (ca. 3500-1200) onwards and reached their zenith in the Roman period, from that time 45 dams are known. ${ }^{50,51}$ All along the course of the dam are the remains of rebuilds and repairs, mostly in the form of later supporting buttresses, but also later sluices and other design modifications, which show at least four phases of use and renovation. In some cases, such as the Harbaqa dam, the continuity of use of the dam has led to controversy over the original date of the structure. It has been suggested that the Harbaqa Dam was not built in the Roman period but rather was an Umayyad construction. ${ }^{52}$ However, a careful examination of textual evidence, radiocarbon dates and settlement evidence indicate that 29 of the 45 dams (64\%) firmly dated to the Roman and late Roman periods seem to had been built in the $3^{\text {rd }}$-century AD or later, six of which seem to had been constructed in the $3^{\text {rd }}$ or early $4^{\text {th }}$ centuries themselves. ${ }^{51}$ These data point to a strong move towards building dams in the late Roman period. Dams like the $10 \mathrm{~m}$ high Çavdarhisar (Kütahya), 16m high Örükaya and Böget (Aksaray) in central Anatolia, Ildırı near Çeşme date back to the Roman period; the three Dara-dams (Mardin), with the first being one of the oldest arch dams, as well as Löştüğün, Sihke, Sultan dams date back to the early Byzantine period; some of the dams around Van in eastern Anatolia might date to the middleages. ${ }^{25,31,53}$ In addition, Faruk-dam (Van) might go back to the Urartu- period, whereas other opinions put them to the $10^{\text {th }}-14^{\text {th }}$ centuries, as contemporary of some dams in Iran. ${ }^{54-56}$

\section{Early eastern asia civilizations}

Many earthen dams of moderate height (in some cases, of great length) were built by the Sinhalese in Ceylon after the $5^{\text {th }}$ century $\mathrm{BC}$ to form reservoirs or tanks for extensive irrigation works. The Kalabalala reservoirs (formed by an earthen dam $24 \mathrm{~m}$ high and nearly $6 \mathrm{~km}$ in length) had a perimeter of $60 \mathrm{~km}$. It is a moderate dam of height (in some cases of great length) built by the Sinhalese in Sri Lanka after the $5^{\text {th }}$ century $\mathrm{BC}$ to store monsoon rainfall for irrigating the agricultural lands around the ancient capital of Anuradhapura. It is still in use today. In China, dams and reservoirs are numerous and have had a profound effect on the country's development and people. According to the Zhang ${ }^{57}$ in 2000, there were 22,104 dams over the height of $15 \mathrm{~m}$ operating in China. Of the world's total large dams, China accounts for $20 \%$ of them; $45 \%$ of which are used for irrigation. Also, China has a long history on dams. ${ }^{58}$ The Qin era was marked by the construction of the so called "three great hydraulic engineering projects of the Qin"; The Dujiangyan in Sichuan, the Zhengguo Canal in Shaanxi and the Lingqu Canal in Guangxi. ${ }^{59}$ The Dujiangyan is an ancient irrigation and flood control project in Dujiangyan City in Sichuan province, which has been originally constructed around 256 BC. The system's infrastructure is on the Min River (Minjiang), the longest tributary of the Yangtze. ${ }^{60} \mathrm{Li}$ Bing is a famous Chinese engineer and politician of the Warring States period. He served for the state of Qin as an administrator and his son headed the construction of the Dujiangyan, which harnessed the river by channeling and dividing the water rather than simply following the old way of dam building. It is still in use today to irrigate over $5,300 \mathrm{~km}^{2}$ of land in the region. ${ }^{61}$ The Zhengguo Canal in Shaanxi is an excavated canal of $150 \mathrm{~km}$ long, from the Jing river west of Mount Zhong as far as Hukou. It was designed by the water engineer named Zheng Guo in order to irrigate the Guanzhong plain (of about $27,000 \mathrm{~km}^{2}$ ), north of Xi'an. By the time of its completion in 246 BC, during the Han dynasty, the canal was already much silted. Under the supervision of Bai Gong, a new canal was cut to feed the irrigation in 95 BC. ${ }^{62}$ The Lingqu canal is in Shaanxi, near Guilin, in the northwestern corner of Guangxi, China. It connects Xiang river (which flows north into the Yangtze) with Li river (which flows south into the Gui River and Xijiang), and thus it is part of a historical waterway between Yangtze and Pearl River Delta. ${ }^{63}$ It was the first canal in the world to connect two river valleys and enabled boats to travel $2,000 \mathrm{~km}$. It was built in $214 \mathrm{BC}$ during the Qin dynasty (221-206 BC). The river diversion dam still exists (Figure 28A). Another example is the small Tuo ShanYan dam. It is a key hydro-work in Yinjiang town in Ningbo City, Zhejiang province. It was built on Yinjiang River in 833 AD (Figure 28B). It is greatly contributed to Ningbo city, a current big port city of China and had become a key hydro-infrastructure to the city's existence and development, and irrigation of the countryside since 1987 when a bigger dam was built at upper reach to control water of the river. ${ }^{64}$ Tuo Shan Yan dam functioned an important role in the local water management and multiple uses such as:

a. Regulation of the river water;

b. Elimination of the flood risks;

c. Prevention of seawater intrusion; 
d. Urban water supply;

e. Irrigation;

f. Navigation; and touristic development. ${ }^{64}$ City.

Finally, it has played a key role in the urban history of Ningbo
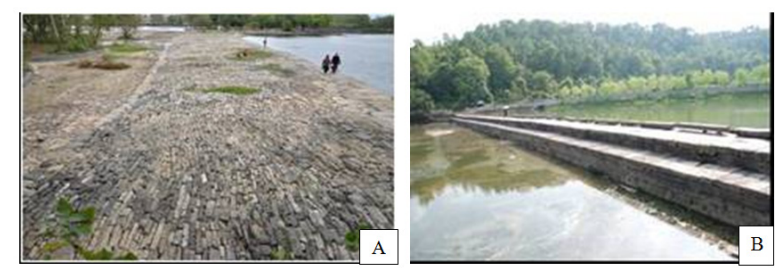

Figure 28 Ancient dams still in operation: (A) Part of the diversion dam in Lingqu canal, with part of the Xiang River left without water flow By permission of A. N.Angelakis). (B) Tuo ShanYan dam. ${ }^{64}$

\section{Medieval times}

\section{Byzantine period (ca. 330-I 204 AD)}

In the Netherlands, a low-lying country, dams were often applied to block rivers in order to regulate the water level and to prevent the sea from entering the marsh lands. Such dams often marked the beginning of a town or city because it was easy to cross the river at such a place, and often gave rise to the respective place's names in Dutch. For instance, the Dutch capital Amsterdam started with a dam through the river Amstel in the late $12^{\text {th }}$ century, and Rotterdam started with a dam through the river Rotte, a minor tributary of the Nieuwe Maas. The central square of Amsterdam, covering the original place of the 800 -year-old dam, still carries the name Dam Square or simply the Dam.

Seljukide period in anatolia: The Great Seljukides $\left(10^{\text {th }}-13^{\text {th }}\right.$ century $)$ had constructed several dams in Iran and Turkmenistan, outside the actual territory of Turkey, where the existence of only two dam sites, impounded by the reservoirs of modern Altinapa and Sille dams near Konya, are reported according to ancient documents. ${ }^{65}$

\section{Sui, tang and song dynasties in china (58 I- I I 27AD)}

Great reservoirs were not the most characteristic of the sophisticated Chinese hydraulic technique, although the still existing Anfengtang or Shao reservoir dates back to before the "Warring State Period (420$221 \mathrm{BC})$. Anfengtang dam rested on a foundation of sand and gravel and consisted of alternating layers of straw and earth, into which a line of chestnut piles was driven upon completion of the embankment. The latter closed off a plain between two tributaries to the Huai River towards the north and west. It is still in operation today and impounds 100 million $\mathrm{m}^{3}$ of irrigation water. ${ }^{66}$ During the Sui Emperor Wen (589-604) era, two major projects were built: The Grand Canal and the great wall of the Qin Empire. The canal made transportation to his capital much easier and it is now the longest canal in the world. ${ }^{67}$

\section{Venetian period (ca. I 204-I669 AD)}

The Venetians established themselves on the Island gradually from $1210 \mathrm{AD}$ turning out the Genoans who had taken advantage of the turmoil. Crete was valuable to the Venetians due to its position. It had contributed to the growth of Venetian trade in the East. During Venetian rule, some of the most important technical and architectural projects on the island were constructed. One of the most characteristics examples of these are the new walls of Heraklion, and the largest Venetian fortification work on Crete and in the entire Mediterranean. Despite, the modern structure and character of the city, the walls are a jewel that preserves important memories. The enormous defensive work is complemented by the sea fortress Rocca a Mare (Koules) at the city port and magnificent, unique buildings such as Loggia (Nobblemens Club) and the Fountain of Francesco Morosini. They are the crowning jewels in the water supply project that started at the springs of Mt Juktaz. ${ }^{46}$

\section{Aztec civilization (ca. I 200-I500 AD)}

A few centuries before the arrival of the Spanish conquerors in 1518 AD the Aztecs attained supremacy in Mexico. During Aztec civilization, dams were built for storing water in the rainy seasons to use during the dry periods. The oldest such structure found so far is the Purron earth dam near San Jose Tilapia at the southern end of the Tehuacan valley, $260 \mathrm{~km}$ southeast of Mexico-City ${ }^{68}$ Aztec King Itzcoatl (1428-1440) had 9km long dikes built from Tenochtitlan to the south and north. These isolated the western part of Lake Texcoco and together with a bifurcating western dike provided road accesses to the city. Under King Montezuma, I (1440-1469), a 16 km long dam farther east was added. For its construction, Nezahualcoyotl (1418-1472) the king of Texcoco on the eastern shore of the lake, collaborated as the hydraulic expert.

\section{Modern times}

\section{Ottoman period (ca. mid I4 $4^{\text {th }}-1923$ AD)}

During the Ottoman period $\left(13^{\text {th }}-20^{\text {th }}\right.$ century $)$ some dams were built. In the period of 1620 to 1839 , the Kırkçeşme system is supported by four dams, the Taksim system by three dams, with heights up to $17 \mathrm{~m}$ and crest lengths up to $104 \mathrm{~m}^{31,65,69,70}$ (Figure 29). All these dams, Kırkçeşme and Taksim systems as well as the Taşlımüsellim-Edirne system are for the large part still in operation. The Elmalı I dam, constructed in 1893 on the Asian side of İstanbul, is also still in operation; Şamlar in İstanbul, Maden near Adapazarı, Semalı near Amasya are other interesting dams of the Ottoman period. ${ }^{53,65}$ The method of constructing the dam was not very different from the methods used by the ancient Anatolia civilization. However, some improvements were made and they are used for water supply purposes. Ottoman dams were formed by two masonry walls with an impervious fill between them. The difference from the old techniques that pozzolanic cement was used to bind the stones with the lead used to assure the total impermeability. Also, spillways did not exist on dams. The crest and the downstream of dams were lined with marble. ${ }^{3}$

\section{Present times (I 800 AD to the present)}

\section{Aswan low dam}

The history of modern water management in Egypt begins with the construction of the Old Aswan Dam in 1902 and barrages on the Nile in the $19^{\text {th }}$ and early $20^{\text {th }}$ century. The Old Aswan Dam partially stored the waters of the Nile to allow the growing of multiple crops per year in the Nile Delta, while the barrages raised the water level of the Nile so that water could be diverted into large irrigation channels running 
in parallel to the river. The Aswan Low Dam is a gravity masonry buttress dam on the Nile River in Aswan, Egypt. The dam was built at the first waterfall of the Nile and it is located $690 \mathrm{~km}$ south-southeast of Cairo. It was initially constructed between the period of 1899 and 1902. It was the largest masonry dam in the world. The dam was designed to provide storage of annual flood water and supplement dry season flows to support greater irrigation development and population growth in the upper part of Egypt. The dam, originally limited in height by conservation concerns, worked as designed, but provided inadequate storage capacity for planned development. The dam was raised twice, in the periods of 1907-1912 and 1929-1933 for the height increase of 5 and $10 \mathrm{~m}$, respectively. These heightening still did not meet irrigation demands and it was nearly over-topped in spite the effort to maximize pool elevation. ${ }^{71}$

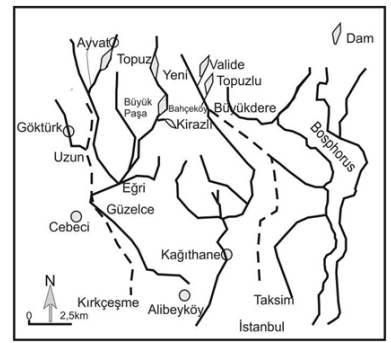

Figure 29 Ancient Ottoman dams in İstanbul and the alignment of Kırkçeșme and Taksim long-distance water conveyance systems. ${ }^{50}$

\section{Aswan high dam}

In the last century, dams (barrages), branches and main canals and annual small storage-capacity reservoirs have been constructed to safeguard Egypt from devastating high floods, droughts and to secure water needs of growing population. Unfortunately, it was realized in the late 1930s, that all these works had not satisfied the country's needs and the desire for comprehensive control of the Nile flow. Planning for the "Aswan High Dam" (HAD) began in 1954. The construction started in 1960 and the dam was effective in 1970. The HAD was constructed on the River Nile, $7 \mathrm{~km}$ south of Aswan. It is a rock dam with grout curtain and clay core. Its total length is $3600 \mathrm{~m}$ and its height $111 \mathrm{~m}$ above the river bed. The storage capacity of its lake is $162 \mathrm{~km}^{3}$. Its hydropower station capacity is $109 \mathrm{kWh}$ per year. ${ }^{72}$ The High HAD has had significant impacts on the economy and culture in Egypt. The most important effect is that it converted a highly variable annual Nile flow, into a predictable source of a constant supply. Water in the lake behind the Dam is available for release any time during the year, so seasonal variability can be manipulated to deliver supplies of water that match the optimal demand pattern.

Assiut barrage: Since more than 100 years ago, Assuit, barrage was built to provide the water into the Ibrahimiya Canal, the largest irrigation canal in Egypt. This is by diversion of river water into the cancel during the low water season. The barrage is a gravity dam consisted of around $95,000 \mathrm{~m}^{3}$ of concrete; $64,600 \mathrm{~m}^{3}$ of masonry; $1,824,000 \mathrm{~m}^{3}$ of earthwork; $95,000 \mathrm{~m}^{3}$ of pitching and more than 4,000 ton of pipes made from cast iron. ${ }^{73}$

Delta barrage: The barrage was used for controlling irrigation and navigation processes in the two branches of the Nile River downstream of Nile division north the Egyptian capital, Cairo. The Delta Barrage is shown in Figure 30. The barrage is a gravity-type dam. Its construction started at 1833 and continued for 30 years. Accordingly, for this long period of construction, perhaps a problem caused in the foundation affected its quality. Thus, its main irrigation purpose had to be largely restricted for safety reasons. ${ }^{74}$

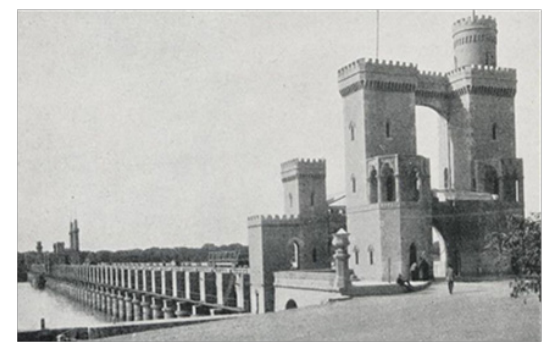

Figure 30 Aswan dam Barrage in the Delta. ${ }^{75}$

Modern dams in iran: Modern dam construction in Iran began six decades ago. The study and design of large storage dams began in 1948 while their construction started in the late 50's. The Bakhtiari Dam as the highest double arch concrete dam in the world is currently under construction on the Bakhtiari River within the Zagros Mountains on the border of Lorestan and Khuzestan Provinces. The height of the dam is $325 \mathrm{~m}$. The Catchment area is $6,288 \mathrm{~km}^{2}$ and the capacity of hydropower station is $1500 \mathrm{MW}$. Construction of the dam began on March 25, 2013. One of the most interesting dams from construction point of view is Kosar dam which is located in a narrow gorge. The dam height is $144 \mathrm{~m}$ and the river width is ranges from 6 to 8 meters. The dam abutments at both sides are sub-vertical from foundation up to the elevation $58 \mathrm{~m}$ a.s.l. (The riverbed is at elevation $500 \mathrm{~m}$ a.s.1.). The gorge width at this elevation is about 40 to $50 \mathrm{~m}$ which makes the construction of the dam very difficult and costly within this height range. So, according to the natural shape of the site an exclusive and quite different method of construction has been adopted. A $2 \mathrm{~m}$ thick metal platform was constructed at elevation $527 \mathrm{~m}$ a.s.l. (Figure 31). The gorge below this elevation has a discharge capacity of $2700 \mathrm{~m}^{3} / \mathrm{s}$. During wet season the flood currents along the river under the platform and at the same time concreting of the dam could be carried out above that. To carry out the construction work below this platform during dry season, a diversion system was constructed which consists of a $5 \mathrm{~m}$ diameter tunnel with a length of 500 and a $6 \mathrm{~m}$ high cofferdam. The tunnel has a maximum discharge capacity of $60 \mathrm{~m}^{3} / \mathrm{s}$. The concrete volume below this platform amounts $30,000 \mathrm{~m}^{3}$.

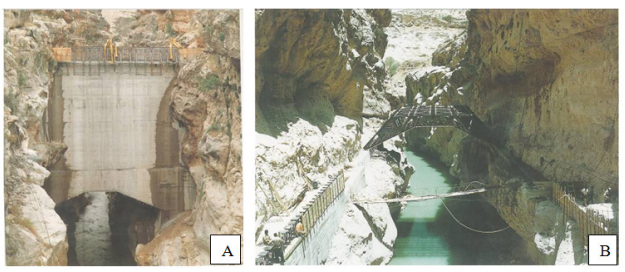

Figure 3 I Kosar dam, (A) Platform, (B) dam on the platform, Height above foundation $(\mathrm{m})$ : 144 .

The dam concreting was carried out in 50 to $75 \mathrm{~cm}$ thick layers from upstream to downstream. The dam from foundation up to elevation $580 \mathrm{~m}$ a.s.l. was designed as a concrete plug and from elevation 580 $\mathrm{m}$ a.s.l. up to the crest level was divide into $40 \mathrm{~m}$ length blocks and two $18 \mathrm{~m}$ and $12 \mathrm{~m}$ blocks in the right and left abutment. The grout curtain length at the two abutments amounts to $510 \mathrm{~m}$ which has an area of $63,000 \mathrm{~m}^{3}$ and it is constructed in three layers down to 
elevation $430 \mathrm{~m}$ a.s.1. (70m below riverbed). Kosar dam is located on Kheyrabad river at a distance of $42 \mathrm{~km}$ from Behbahan city in Khuzestan province in south of Iran. Probing in the past, knowledge, and experience gained in the construction of dams, high scientific standards, self- reliance and confidences as well as proper strategies have had an important role in all the achievements. At present there are 157 dams in operation and about 90 dams under construction. Two of the modern dams constructed and in operation, just as an example are shown in Figure 32. ${ }^{76}$

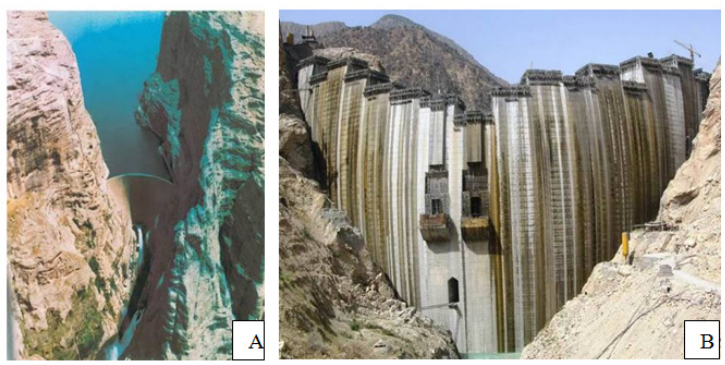

Figure 32 (A) Dez dam, height 203m, 54 years old in Khoozestan Province, (B) Karoon 4 dam, height 230m, 5 years old in Charmahal Bakhtiari Province.

Marathon dam - a modern monumental dam in greece: The marathon reservoir was created by the construction of the dam immediately downstream of the confluence of streams of Charadros and Varnavas. It is a concrete gravity dam entirely coated in Pentelic marble, which makes it unique globally. Also, the building with the valves is a copy of the treasure of the Athenians in Delphi. The dam was constructed by the American company Ulen from 1928 until 1931 , in order to provide potable water to the urban complex of Athens. Its height is $63 \mathrm{~m}$, the length of the crest is $285 \mathrm{~m}$ and its volume is $179,000 \mathrm{~m}^{3}$. The capacity of the reservoir amounts to 41 million $\mathrm{m}^{3}$.

Three gorges dam in china: The Three Gorges Dam is the largest hydroelectric dam in the world. It is located in the middle of the three gorges on the Yangtze River, the third longest in the world, in the Hubei Province of China. The project was approved by the Chinese government in 1992. However, construction didn't begin until 1994. It was completed in 2009 . The $\$ 25$ billion project is being internationally funded by companies, export credit agencies, and banks from Canada, Switzerland, Germany, France, Sweden, and Brazil. Controversy about the project arises from human rights issues (as many as 1.3-1.9 million people have been forced to be relocated) and environmental impacts. ${ }^{77}$ The Chinese Government has four goals for the Three Gorges Dam project that are to control flood water, Power Generation, Navigation, and Tourism.

\section{Modern dams in anatolia}

Atatürk Dam completed in 1990 on the Euphrates River is located in the Sanliurfa Province of the Anatolia region of southeast Turkey. It is the largest dam in the Anatolia and ranks sixth amongst the largest earth-and-rock fill embankment dams in the world. The rockfill dam with the central core has a crest length of $1,820 \mathrm{~m}$ and height of $184 \mathrm{~m}$. It has a volume of 84.5 million $\mathrm{m}^{3}$. Atatürk Dam has a catchment area of $92,240 \mathrm{~km}^{2}$ and annual inflow of 26,585 million $\mathrm{m}^{3}$. Atatürk Dam project has been constructed to control flood water, irrigation and power generation.

\section{Emerging trends}

In the future, multipurpose dams (hydropower, navigation, flood control, water supply, and irrigation) will be mainly constructed. Future construction of large dams is expected to lead to significant increase in global hydroelectricity. ${ }^{78}$ While careful cost benefit analysis in dam construction worldwide is crucial for sustainable development, ${ }^{79}$ methods leading to a reduction in construction and operation costs are currently adopted. More specifically, gravity and arch dams are constructed with lower cement content, underground water conduits, and spillways that support higher specific discharges. ${ }^{80}$ Also, modern design can lead to efficient and continuous irrigation by means of surface and subsurface drainage. Variable-level intakes are used to ensure water intakes from the upper reservoir levels, where water quality and temperature can be preferable for water uses and ecological factors (e.g., the Bakun Dam in Malaysia, and the Katse dam in Lesotho. ${ }^{80}$ Good examples include the new Three Gorges dam in China, the Eibenstock Dam in Germany, the Grand'Maison Dam in France, the Tarbela, Kalabagh, Diamer Bhasha, Naulong, Kurram Tangi, Nai Gaj, Mirpur, and Darawat dams in Pakistan, and the Kariba or Cahora Bassa dams in Africa ${ }^{81,82}$ Most of these dams are constructed using the method of Gabarband, Trai, and Khushkaba, fountain system, where the government or locals constructed a wall in the spell way of river and log the water for agriculture or power resources purposes using advanced technology. Also, the people of Indus valley civilization have the ability to construct a Garbarband on Indus River near Harappa and Mohenjo-daro for the purpose to raise the water slope, and to divert waters into nearby lands for agriculture and irrigation purposes. However, both of these historical sites have been destroyed due to sudden breaking of these gabrabands.

\section{Terbela dam, pakistan}

Tarbela Dam on the Indus River in Pakistan is the second largest dam in the world by structural volume and the largest earth filled dam in the world. It is located in Haripur District, Hazara Division, Khyber Pakhtunkhwa, about $50 \mathrm{~km}$ northwest of Islamabad. The dam is $148 \mathrm{~m}$ high above the riverbed. The dam forms the Tarbela Reservoir, with a surface area of approximately $250 \mathrm{~km}^{2}$. The dam was completed in 1974 and designed to store water from the Indus River for irrigation, flood control, and the generation of hydroelectric power. ${ }^{83}$ The project is located at a narrow spot in the Indus River valley, at Tarbela in Swabi, shortly located at the point from where the District Swabi starts. Here the river formerly split around a large island close to the left bank. The main dam wall, built of earth and rock fill, stretches $2,743 \mathrm{~m}$ from the island to river right, standing $148 \mathrm{~m}$ high.

\section{Diamar basha dam, pakistan}

The dam is located on Indus River, about $315 \mathrm{~km}$ upstream of Tarbela Dam, $165 \mathrm{~km}$ downstream of the Northern Area capital Gilgit and $40 \mathrm{~km}$ downstream of Chilas. The method used for the construction of Diamar Basha dam is Gabarband and Khushkaba system. The dam is the world's highest Roller Compacted Concrete Dam. The proposed dam would have a maximum height of $270 \mathrm{~m}$ and impound a reservoir of about $9.25 \times 10^{9} \mathrm{~m}^{3}$, with live storage of more than $7.89 \times 10^{9} \mathrm{~m}^{3}$. Mean annual discharge of Indus River at the site is $6.2 \times 10^{10} \mathrm{~m}^{3}$. Thus, the dam will impound $15 \%$ of the annual river flow. The dam project would cover an area of $110 \mathrm{~km}^{2}$ and extend $100 \mathrm{~km}$ upstream of the dam site up to Raikot Bridge on Karakoram Highway. 
The main outcome of the dam is; availability of annual surface water storage for supplementing irrigation supplies during low flow periods, energy resources, reduction of dependence on thermal power, thus saving foreign exchange, employment opportunity, particularly to the locals, during the construction and operation [83,84]. The dam is located on Indus River, about $315 \mathrm{~km}$ upstream of Tarbela Dam, $165 \mathrm{~km}$ downstream of the Northern Area capital Gilgit and $40 \mathrm{~km}$ downstream of Chilas. The method used for the construction of Diamar Basha dam is Gabarband and Khushkaba system. The dam is the world's highest Roller Compacted Concrete Dam. The proposed dam would have a maximum height of $270 \mathrm{~m}$ and impound a reservoir of about $9.25 \times 10^{9} \mathrm{~m}^{3}$, with live storage of more than $7.89 \times 10^{9} \mathrm{~m}^{3}$. Mean annual discharge of Indus River at the site is $6.2 \times 10^{10} \mathrm{~m}^{3}$. Thus, the dam will impound $15 \%$ of the annual river flow. The dam project would cover an area of $110 \mathrm{~km}^{2}$ and extend $100 \mathrm{~km}$ upstream of the dam site up to Raikot Bridge on Karakoram Highway. The main outcome of the dam is; availability of annual surface water storage for supplementing irrigation supplies during low flow periods, energy resources, reduction of dependence on thermal power, thus saving foreign exchange, employment opportunity, particularly to the locals, during the construction and operation. ${ }^{81,82}$

\section{Ghazi barotha hydropower project, pakistan}

The Ghazi Barotha Project intends to utilize the fall of the Indus River between the tail-race of Tarbela dam and the confluence of the Indus and Haro rivers to produce electricity. The Project consisted of three basic components: 1 . a diversion barrage on the Indus river $7 \mathrm{~km}$ downstream of Tarbela dam, 2. a power channel about $52 \mathrm{~km}$ long, and 3. a 1,425 MW power-generating complex on the left bank of the Indus river downstream of the Attock gorge. The plan of the project was constructed using the pattern of Dockyards of Lothal during Indus Valley Civilization with little update per recent advance technologies. The barrage is located just upstream of the left bank village of Ghazi in Haripur district and it is impounding a pond. Water from the barrage pond has passed through a regulating headworks structure into an open power channel with a design capacity of $1,600 \mathrm{~m}^{3} / \mathrm{s}$. The power channel has terminated in a bay near the village of Barotha, from which water has flowed through penstocks to a powerhouse and hence through a tailrace channel, $2 \mathrm{~km}$ long, discharging into the Indus River (Figure 33). The planned average water release during the leanest 130 days from the barrage at Ghazi Barotha in the low-flow period is about $60 \mathrm{~m}^{3} / \mathrm{sn}$ or $7 \%$ of the existing average flow of $830 \mathrm{~m}^{3} / \mathrm{sn}$ during the same period. Over the 230-day low-flow season from mid-October to mid-May, proposed releases are less than $12 \%$ of the existing flow downstream of Tarbela.
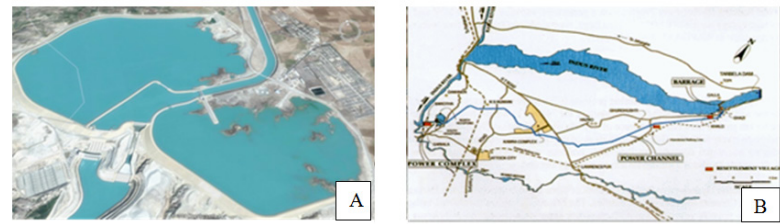

Figure 33 Ghazi Barotha Hydropower project: (A) Spell way and waterlogged area and (B) general plan of the channel at Terbala. ${ }^{85}$

\section{Discussion and conclusion}

Throughout the ages, societies of the world greatly benefited from building infrastructure for water resources systems management.
By means of dam construction and operation, different civilizations managed to efficiently cover various water demands (e.g. water supply and irrigation) through long drought periods. In addition, dams have been constructed for navigation, flood protection, and energy production. This paper reviews important advances in dam construction throughout the history of mankind, spanning from prehistorical to modern times. Geographically, it is extended to the hydraulic engineering of dam-technologies in different regions of the world comprises of Europe, Middle East, Africa, Mesoamerica, and Southwest and Eastern Asia. The role, functionality, operation, and technical characteristics of major water dams in different civilizations globally are discussed, in a chronological order. Technologies of ancient dam construction are reviewed, and detailed information on dam durability, sustainability, and adaptability to environmental factors are presented. In general, the use of traditional knowledge does not directly apply techniques of the past but instead, try "to understand the logic and the principles of the past hydro-practices". ${ }^{86}$ Traditional knowledge allowed ancient societies to keep ecosystems in balance, to leave in harmony with environment, carry out outstanding technical, artistic, and architectural work that has been universally admired. Traditional knowledge incorporates innovation in a dynamic fashion, achieving local and environmental sustainability and renewing and adapting itself. A multitude of socioeconomic factors set progress in water resources management, disproportional in different areas worldwide, in ancient and modern times. Effective measures for satisfying water demands in the developing world may be still in their early stages, notably, compared to historical achievements in dam construction and operation over the centuries. Characteristic is the example of water supply and sanitation systems in Pakistan and India, which can be characterized as non-developed, compared to advances of ancient civilizations (e.g., Egyptian, Indus valley and the Minoan civilizations) thousands of years ago. This study highlights the importance of major achievements in water resource systems infrastructure in the history of mankind, and bridges the gap between ancient technologies and historic advances in the field of hydraulic dams, with modern aspects of constructions and water resource systems operation. Knowledge of ancient technologies and historic achievements in water resources management can have some importance for developing strategies to tackle future water challenges in a changing world. In ancient Egyptian civilization since $c a$. 6000 BC, people had constructed dams and canals to control Nile River flood and developed irrigation systems. The same tools still have been used in modern times. The Sabaens, ancient Yemen people managed to keep their dam stood for over 1,000 years before the existence of concrete and the recent advanced construction technologies. In the $2^{\text {nd }}$ millennium $\mathrm{BC}$, Minoans attempted to manage the irrigation water by regulating the flow of the streams through a system of two dams, in order to protect arable land from erosion after heavy rainfall and also to irrigate their fields. Two such characteristics paradigms were discovered in the valley of Choiromandres located on the southeastern Crete and on the small island of Pseira (Mochlos) located in the northeastern Crete. This review described historical hydraulic engineering and rainwater harvesting system of Harappa, Mohenjo-daro, Lothal, and Dholavira of the Indus Valley civilization (ca. 2600-1900 BC). Four major elements stand out and they are the well-developed swimming pools, rainwater storage system and hydraulic engineering, underground water tanks, and dockyard. The most important contribution of Indus valley civilization is the complete knowledge of advanced hydraulic engineering technologies, 
rainwater/floodwater harvesting system, water collection and recycling often evolved through trial-and-error modifications after the systems were initially constructed. They were in a full command on the scientific discoveries, or technical advances in planning, design, construction, and engineering. In some cases, the recent system of Tarai in Sind, Khoskhaba, Sailaba, and Qanats in Balochistan (Pakistan) were constructed using the engineering technologies of Indus valley civilization. It should be concluded that the current technological approach of hydraulic engineering, rainwater harvesting, cultural and socio-economic development, drainage and sanitation system of Pakistan and India are underdeveloped as compared to the ancient people of Indus valley civilization. Dams at prehistoric times were of small-scale hydraulic works (of less than $1000 \mathrm{~m}^{3}$ of capacity), mainly constructed by unconsolidated materials (i.e. stones and soil as a bonding material), and they were operated for regulation of water flow and rainwater harvesting. Recent civilizations (e. g. Hellenic, Chinese, Mesoamericans, Romans, Byzantines, Venetians, and Ottomans), inherited the dam-technologies and developed them further. They substantially increased the application scale and implemented dam projects not only for water supply and irrigation but also for navigation, flood production, and recreational purposes. In addition, during the historical times dams were implemented for diversion of the water flow (Figure 29). Also, clay soils were started to be used as supplementary material since the early Classical period. However, later on during the Roman period the invention of concrete technology (the so-called caementitium opus) made possible to also build even larger other hydraulic works including dams. The differences between ancient and modern time dam-technologies are mostly found in the apparatus and the scale of applications with practically no differences in the fundamental principles used. For examples, Sadd el-Kafara in Egypt, the oldest known dam in the world, adopted the same building principle of modern embankment dams as it consisted from two masonry shoulders supporting a central core of sand and gravel.

Another important point of the ancient hydro-technologies in comparison to the modern is the design and construction principles. Naturally, it is difficult to estimate the design and construction principles of ancient "Engineers" but it is notable that several ancient works have operated for very long periods, some until recent times. Examples are: the Dujiangyan hydraulic works in Sichun county, Lingqu canal in Xing' an county, near Guilin, in the northwestern corner of Guangxi, and the Shan Yuan Dam a key hydro work for Ningbo City, China, and Kalabalala dam in Sri Lanka. On the other hand, engineers in our times typically design constructions for functioning about 40 to 50 years, as dictated by economic considerations. Thus, the sustainability and durability of Minoan water technologies should be further studied. Future dam construction, especially in the developed world, is expected to focus on dams that are not only built for a single water use (e.g., irrigation or water supply). Multipurpose dams are being constructed, combining multiple water uses, such as efficient and continuous irrigation, water supply and power generation using advanced technologies, and flood control, by adopting methods leading to reduced operation and construction costs. This generally accepted tendency is expected to drive a substantial increase in global hydroelectricity.

Finally, even presently there are under-developed countries lacking a modern system of hydraulic engineering, rainwater harvesting, drainage, and sanitation system. Such countries can learn from the history and improve their hydraulic engineering and flood water harvesting system.

\section{Acknowledgement}

None.

\section{Conflict of interests}

The authors do not declare any actual or potential conflict of interest including any financial, personal, or other relationships with other people or organizations that could inappropriately influence this work.

\section{References}

1. Şentürk F. Hydraulics of dams and reservoirs. LLC, NY, USA: Water Resources Publication; 1994.

2. Haut B, Zheng XY, Mays L, et al. Evolution of rainwater harvesting and heritage in urban areas through the millennia: A sustainable technology for increasing water availability. In: Willems WJH, van Schaik HPJ, editors.Water and Heritage: Material, Conceptual, and Spiritual connections. Fruitweg 46A, 2321 DH Leiden, The Netherlands: Sidestone Press; 2015. 3: 37-56.

3. Konig KW. The rainwater technology handbook: rainharvesting in building. Dortmund, Germany: Wilo- Brain; 2001.

4. Angelakis A. Hydro-technologies in Minoan Era. Water Science and Technology: Water Supply. 2017.

5. Antoniou GP, Kathijotes N, Angelakis AN, et al. Historical Development of Technologies on Water Resources Management and Rainwater Harvesting in the Hellenic Civilizations. Inter Journal of Water Resources Development. 2014;30(4):1-14.

6. Jarrige $C$. The figurines of the first farmers at Mehrgarh and their offshoots. Pragdhara. 2008;18:155-166.

7. Quddus SA. Sindh, the land of Indus civilisation. Karachi, Pakistan: oyal Book Co; 2010.

8. Mallah Q. An Archaeological Assessment of Taung Valley of SindhKohistan Pakistan. Ancient Asia. 2010. 2:93-112.

9. Biagi P. The Mesolithic settlement of Sindh (Pakistan): A preliminary assessment. Praehistoria. 2003;4-5:195-220.

10. Markonis Y, Angelakis A, Christy J, et al. Climatic variability and the evolution of water technologies in Crete, Hellas. Water History. 2016;8(2):137-157.

11. Betancourt PP. Dams and Water Management Systems of Minoan Pseira. USA: INSTAP Academic Press. 2012. p. 1-92.

12. Watrous LV. The harbor complex of the Minoan town at Gournia. American Journal of Archaeology. 2012;116(3):521-541.

13. Gray HF. Sewerage in ancient and mediaeval times. Sewage Works Journal. 1940;12(5):939-946.

14. Khan S. Sanitation and wastewater technologies in Harappa/Indus valley civilization (ca. 2600-1900 BC). Evolution of Sanitation and Wastewater Technologies through the Centuries. 2014;25:1-16.

15. Subramanian T. The rise and fall of a Harappan city. Frontline. 2014;27:12

16. Violett P. Water engineering in ancient civilizations: 5,000 years of history. Madrid, Spain: International Association of Hydraulic Engineering and Research (IAHR); 2007.

17. Wales JD. The Free Encyclopedia. 2004.

18. Mulchandani ASD. A walk through Lothal. 2017 
19. Kenoyer JM. Ancient cities of the Indus valley civilization. USA American Institute of Pakistan Studies; 1998.

20. AE. Agriculture and horticulture in ancient Egypt. Egypt: Ancient Egyptian agriculture and horticulture: irrigation, ploughing and planting, harvest, crops; 2017

21. Van Loon M. The Beginning of the Middle Bronze Age in Syria. Ägypten und Levante/Egypt and the Levant. 1992;3:103-107.

22. Saxena KR, Sharma V. Dams: Incidents and accidents. CRC Press. 2004

23. Jansen RB. Dams from the beginning. Dams and Public Safety (Part 1). 1980. p. 1-57.

24. Fahlbusch H. Early Dams. History Association; 2017.

25. Schnitter N. A history of dams: The useful Pyramids. Balkema; 1994 p. 266.

26. In Lake Moeris. 2017

27. Brown GO, Hager WH, Garbrecht JD. In Henry PG Darcy and other pioneers in hydraulics. American Society of Civil Engineers. 2013.

28. Verner M. The Pyramids: The Mystery, Culture, and Science of Egypt's Great Monuments. Grove/Atlantic, Inc. 2007.

29. Öziş ÜAY, Alkan A, Özdemir Y. Ancient water works in Anatolia. Latest Trends on Cultural Heritage and Tourism. 2010:63-71.

30. Emre K. Essays on Anatolian Archaeology: The Hittite dam of Karakuyu. Wiesbaden: Harrassowitz Verlag; 1993.

31. Bildirici M. In Historical dams of Anatolia (Turkey), Siegburg. Cura Aquarum in Israel-Proceedings of the $11^{\text {th }}$ International Conference on the History of Water Management and Hydraulic Engineering in the Mediterranean Region. 2001;137-143.

32. DSİ. Hittite dam from $1250 \mathrm{BC}$ towards today,. DSİ General Directorate, $5^{\text {th }}$ Regional Directorate, report. 2008.

33. Ozkaldi A. Hatit Dam, Ministry of Environment and Forestry. $5^{\text {th }}$ Regional Directorate, Turkey. 2008.

34. Moustakas S. Representation of the operation of ancient hydraulic works in the Okypodas area. Diploma Dissertation, Water Resources and Environmental Engineering Section, School of Civil Engineering, National Technical University of Athens. 2012:142.

35. Knauss J. Research on the hydraulic works for the infrastructure for the water management during the Mycenaean era. Weilheim, Bavaria, Germany: Society for the Study and Dissemination of the Hellenic history (in Greek). 2002.

36. Kountouri E, Petrochilos, N, Koutsoyiannis D, et al. In A New Project of Surface Survey, Geophysical and Excavation Research of the Mycenaean Drainage Works of the North Kopais: The First Study Season. IWA Specialized Conference on Water and Wastewater, IWA Publishing London; 2012. p. 22-24.

37. Quarterman CK. Ancient Nephilim ooparts - Marib Dam Worked for 1,000 Years. End Time Ministries; 2017.

38. Romey K. Engineering Marvel of Queen of Sheba's City Damaged in Airstrike. National Geograpihic Society. 2017.

39. Öğün B. Urartu irrigation facilities in Van and Amram (Semiramis) channel in Ankara. Anatolia; 1970. p. 51.

40. Belli O. Urartian irrigation canals in Eastern Anatolia. Arkeoloji ve Sanat Yayınları: Arkeoloji ve Sanat Yayinlari, Istanbul;1997.

41. Orhan AH, Taner O, Ecevit E. Urartian water constructions and hydraulics. Journal of Applied Science Research. 2004;2(6):346-354.
42. Wright KR, Kelly JM, Zegarra AV. Machu Picchu: ancient hydraulic engineering. Journal of Hydraulic Engineering. 1997;123(10): 838-843.

43. Mahmoudian SA, Mahmoudian SN. Water and water supply technologies in ancient Iran, chap 5. Evolution of water supply through the Millennia. IWA, London. 2012; 91-126.

44. Mounier RAK, HC. The Archaic Period in New Jersey, (ca. 8000 BC $-1000 B . C$.$) . The state of New Jersey; 2017$

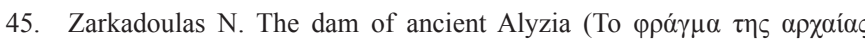

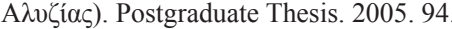

46. Koutsoyiannis D, Zarkadoulas N, Angelakis A, et al. Urban water management in Ancient Greece: Legacies and lessons. Journal of water resources planning and management. 2008;134(1):45-54.

47. GOP. A census of agriculture. Islamabad, Pakistan. 2000.

48. Hodge A. Roman Aqueducts \& Water Supply. London, UKISBN: Gerald Duckworth \& Co. Ltd; 2002

49. Kamash Z. Archaeologies of Water in the Roman Near East: 63 BC-AD 636. Gorgias Press. 2013.

50. Al Muheisen ZTD. Arhanes, Venetian Rule, (1211-1669 A.D). Archanes-asterousia.gr. 2017.

51. Kamash Z. Recent research on Roman dams in the Near East. In: Wiplinger G, editor. Cura Aquarum in Ephesus. Proceedings of the $12^{\text {th }}$ International Conference on the History of Water Management and Hydraulic Engineering, Ephesus, Peeters, Leuven, Paris, 2-10 October, 2004. 233-238.

52. Saliby N. Les installations hydrauliques à Qasr el-Heir el Gharbi In:Techniques et pratiques hydro-agricoles traditionnelles en domaine irrigué, approche pluridisciplinaire des modes de culture avant lamotorisation en Syrie, Actes du Colloque de Damas, 27 Juin-1 er Juillet 1987. Geyer B, editor. Bibliothèque archéologique ethistorique 136, Paris, France. 1987. p. 475-486.

53. Ozis U. Historical water schemes in Turkey. International Journal of Water Resources Development. 1996;12(3):347-384.

54. Ozis U. Historical dams in Turkey. ICOLD. 1999.

55. Garbrecht G. Die Talsperren der Urartäer. Historische Talsperren. Verlag Konrad Wittwer, Stuttgart. 1987

56. Schnitter N. Antike Talsperren in Anatolien. Leichtweiss-Institut für Wasserbau, Mitteilungen.1979.64:1-8.

57. Zhang L. Social impacts of large dams: The China case. South Africa: World Commission on Dams; 2000.

58. World Commission on Dams. Dams and Development: A New Framework for Decision-making. Earthscan Publications Ltd: London, UK and Sterling, VA, USA; 2001. p. 404

59. Anonymous. The Lingqu Canal, one of the Three Great Hydraulic Engineering Projects of the Qin Dynasty (in Chinese). 2005.

60. Holloway A. The legacy of Dujiangyan: China's ancient irrigation system. Ancient Origin. 2003.

61. Zhang K, Hu C. World heritage in China. South China University of Technology Press: Guangdong, China. 2006.

62. Needham J, Ronan CA. The shorter science and civilisation in China. Cambridge University Press; 1995. p. 5.

63. Temple RK. The genius of China: 3,000 years of science, discovery, and invention. Prion Books. 1998.

64. Zheng XY, Min SJ. Tuo Shan Yan Dam and City Ningbo: Exploring 
the Historical Logic of Urban Water Management through a Big City of China. Journal of Earth Science and Engineering. 2017;7:127-135.

65. Çeçen K. Seldschukische und osmanische Talsperren. Historische Talsperren. Wittwer, Stuttgart. 1987:275-295.

66. Needham J. Science and civilisation in China. 4: Physics and physical technology: 3. Civil engineering and nautics. Cambridge University Press. 1971. p. 1-482.

67. Kelley. The Sui Dynasty a Short but Significant Dynasty. China Highlights. 2017.

68. Woodbury RB, Neely JA. Water control systems of the Tehuacan Valley. Prehist Tehuacan Val. 1972.

69. Öziş Ü. The ancient dams of İstanbul. Int Water Power Dam Constr. 1977;7:49-51.

70. Çeçen K. Sinan's water supply system in İstanbul. İstanbul Su ve Kanalizasyon Idaresi: Istanbul, Turkey. 1990. p. 218.

71. Novokshshenov Aswan Dam. 2017.

72. Schamp H. Sadd el-Ali, the High Dam of Aswan. Geowissenschaften in unserer Zeit (in German). 1983;1(2):51-85.

73. Willcocks W, Craig JI. Egyptian irrigation. Egypt: E \& FN Spon Limited; 1913.

74. Platt RR, Hefny MB. Egypt: A Compendium; American Geographical Society New York. 1958.

75. Abu-Zeid M, El-Shibini F. Egypt's high Aswan dam. International Journal of Water Resources Development. 1997;13(2):209-218.
76. Farhangi B. Water melody in the passage of time. Tehran, Iran. 2003.

77. GoChina. The Three Georges Dams Project. 2017.

78. Zarfl C, Lumsdon AE, Berlekamp J, et al. A global boom in hydropower dam construction. Aquatic Sciences. 2015;77(1):161-170.

79. Chen J, Shi H, Sivakumar B, et al. Population, water, food, energy and dams. Renewable and Sustainable Energy Reviews. 2016;56:18-28.

80. Dorcey AH. Large Dams: Learning from the Past Looking at the Future. Workshop Proceedings, Gland, Switzerland, April 11-12, 1997. World Bank Publications. 1997.

81. Tischler J. Light and power for a multiracial nation: The Kariba Dam scheme in the Central African Federation. Springer. 2013. p. 1-323.

82. Davies BR, Beilfuss RD, Thoms MC. In Cahora Bassa retrospective, 1974-1997: effects of flow regulation on the lower Zambezi River. Assoc Int Limnol Theo Appl. 2001:2149-2157.

83. GoP. Paktourist, Terbala Dam Pakistan. 2017.

84. GoP. Pakistan Construction and Quarry JG Significance and Importance of Pakistan's Diamar Basha Dam. Gomal Zam, Command Area Adovocacy Program. 2017.

85. Khan MZ. The Devastating Impact of Ghazi-Barotha Project on Downstream Water Resources, Working Paper Series 21, Sustainable Development Policy Institute (SDPI), Islamabad. 1995:12.

86. Laureano P. Ancient water catchment techniques for proper management of Mediterranean ecosystems. Water Science and Technology: Water Supply. 2007;7(1):237-244. 